\title{
Structure and biological activities of a hexosamine-rich cell wall polysaccharide isolated from the probiotic Lactobacillus farciminis
}

Emmanuel Maes ${ }^{1}$, Irina Sadovskaya ${ }^{2}$, Mathilde Lévêque ${ }^{3}$, Elisabeth Elass-Rochard ${ }^{1}$, Bruno Payré ${ }^{4}$, Thierry Grard ${ }^{2}$, Vassilia Théodorou ${ }^{3}$, Yann Guérardel ${ }^{1}$, Muriel Mercier-Bonin ${ }^{3}$

${ }^{1}$ Univ. Lille, CNRS UMR 8576, UGSF-Unité de Glycobiologie Structurale et Fonctionnelle, 59000 Lille, France

${ }^{2}$ Université du Littoral-Côte d'Opale, Equipe Biochimie des Produits Aquatiques BPA, Institut Régional Charles Violette EA 7394, USC Anses-ULCO, Bassin Napoléon 62327 Boulogne-sur-mer cedex, France

${ }^{3}$ Toxalim (Research Centre in Food Toxicology), Université de Toulouse, INRA, ENVT, INP-Purpan, UPS, Toulouse, France:

${ }^{4}$ Faculté de Médecine Rangueil, Centre de Microscopie Electronique Appliquée à la Biologie (CMEAB), Toulouse Cedex, France

Corresponding author: Muriel Mercier-Bonin (orcid.org/0000-0001-8398-2529) muriel.mercierbonin@inra.fr; tel: + $33(0) 582066458$ 


\section{Abstract}

Lactobacillus farciminis CIP 103136 is a bacterial strain with recognized probiotic properties. However, the mechanisms underlying such properties have only been partially elucidated. In this study, we isolated and purified a cell-wall associated polysaccharide (CWPS), and evaluated its biological role in vitro. The structure of CWPS and responses from stimulation of (i) human macrophage-like THP-1 cells, (ii) human embryonal kidney (HEK293) cells stably transfected with Toll-like receptors (TLR2 or TLR4) and (iii) human colonocyte-like T84 intestinal epithelial cells, upon exposure to CWPS were studied. The structure of the purified CWPS from L. farciminis CIP 103136 was analyzed by nuclear magnetic resonance (NMR), MALDI-TOF-TOF MS, and methylation analyses in its native form and following Smith degradation. It was shown to be a novel branched polysaccharide, composed of linear backbone of trisaccharide repeating units of: $[\rightarrow 6 \alpha \mathrm{Glc} p \mathrm{NAc} 1 \rightarrow 4 \beta \mathrm{Man} p \mathrm{NAc} 1 \rightarrow 4 \beta \mathrm{Glc} p \mathrm{NAc} 1 \rightarrow]$ highly substituted with single residues of $\alpha \mathrm{Glc} p$, $\alpha$ Galp and $\alpha$ Glc $p$ NAc. Subsequently, the lack of pro- or anti-inflammatory properties of CWPS was established on macrophage-like THP-1 cells. In addition, CWPS failed to modulate cell signaling pathways dependent of TLR2 and TLR4 in transfected HEK-cells. Finally, in T84 cells, CWPS neither influenced intestinal barrier integrity under basal conditions nor prevented TNF- $\alpha / \mathrm{IFN}-\gamma$ cytokinemediated epithelium impairment.

Keywords: Lactobacillus farciminis, probiotic, cell wall polysaccharide, structure, immunomodulation, intestinal barrier 


\section{Introduction}

Probiotics are defined as "live microorganisms that, when administered in adequate amounts, confer a health benefit on the host", according to a rewording of the FAO/WHO definition (2001) by an expert panel [1]. Bacteria present in probiotic products typically belong to Lactobacillus genera although other microorganisms (e.g., Bifidobacterium, Gram-negative bacteria and yeasts) have also been proposed as probiotics [2]. A variety of health benefits has been proposed to be associated with the consumption of probiotic lactobacilli, which are frequently related to prophylactic or therapeutic effects in intestinal disorders and diseases, including inflammation reduction, improvement of gut homeostasis, enhancement of epithelial barrier function and modulation of the immune responses [34]. However, despite huge cognitive and applicative developments on probiotic lactobacilli, it is still difficult to date to draw general conclusions on their real health impact. Consequently, the European Food Safety Agency (EFSA) has deemed the vast majority of probiotic health claims as insufficient, in probiotic strain characterization and/or the identification of biomarkers to demonstrate a cause-effect relationship.

This situation has fueled the ambitions of the scientific community to unravel the molecular characteristics of probiotics and identify the effector molecules involved in this bacteria/host interplay. Both in vitro and in vivo studies are generally performed to reveal the capability of probiotic lactobacilli to modulate host-cell-signaling networks and the associated influences on downstream regulatory pathways, including modulation of mucosal and systemic immune responses. The communication between probiotic lactobacilli and intestinal host cells is multifactorial and involves an integrative repertoire of receptors on the host side, that recognize multiple effector molecules on the bacterial side, most of which have been found to be cell-surface associated, like peptidoglycan, teichoic acids and surface proteins [5]. In contrast, the immuno-modulatory role of cell surface polysaccharides has been less extensively investigated. However, the immense chemical diversity of 
the polysaccharides that can be produced by lactobacilli, in combination with their variations in terms of location (i.e., covalently linked to the peptidoglycan: wall polysaccharides; loosely attached to the cell envelope: capsular polysaccharides; released into the surrounding medium: exopolysaccharides), polymer size, and conformational properties, may potentially offer direct signaling effects, depending on the characteristics of the molecule in the cellular context. The corresponding recognition host receptors include C-type lectins (CLRs), Toll-like receptors (TLRs) and dendritic cell-specific intercellular adhesion molecule-3-grabbing non-integrin (DC-SIGN) receptors [6-7], even though the underlying mechanisms are still far from being understood.

An increasing number of studies on polysaccharide-derived immuno-modulatory effects of lactobacilli, for instance in Lactobacillus casei NIZO B255 and Lactobacillus reuteri ASM20016 [6], L. casei Shirota [8], Lactobacillus rhamnosus LOCK 0900 [9] and more recently L. casei LOCK 0919 [10] and Lactobacillus paracasei DG [11], combined with examples on other bacteria, e.g., the polysaccharide-A producing Bacteroides fragilis [12-14], exemplifies the huge potential of these cell surface molecules when it comes to host response modulation.

Lactobacillus farciminis CIP 103136 is a probiotic strain with a scientific and commercial interest. A range of health-promoting properties has been assigned, including an IL10-mediated antiinflammatory profile in a trinitrobenzene sulphonic acid (TNBS)-induced colitis rodent model [15]. The role of nitric oxide release in the lumen by L. farciminis was pointed out [16]. In a latter study with the same strain [17], the L. farciminis treatment was demonstrated to prevent stress-induced hypersensitivity and increase in colonic paracellular permeability. The influence of L. farciminis on the restoration of stress-induced mucin O-glycosylation changes was also shown, and the possible effect of $L$. farciminis on glycosylation enzymes through its anti-inflammatory profile was underlined [18]. Interestingly, the capsular polysaccharide production by the probiotic strain L. farciminis CNCM I-3699 was established [19]. Despite the significant clinical evidence for the health benefits associated 
with the consumption of L. farciminis CIP 103136, the molecular mechanisms underlying these health effects are still poorly described.

Based on this background, the present work aims at isolation, structural analysis and assessment of the biological activities of a novel cell surface polysaccharide isolated from L. farciminis CIP 103136 (which was named CWPS). To evaluate its role in probiotic properties of the bacterium, we first examined its ability to modulate immune response of macrophage-like THP-1 cells and HEK-blue cells transfected with human TLR2 or TLR4 receptors. We then evaluated the modulatory effects of CWPS on the epithelial barrier integrity in T84 intestinal cells with or without a pro-inflammatory cytokine challenge.

\section{Materials and methods}

\section{Bacterial strain and culture conditions}

L. farciminis strain (CIP 103136, Institut Pasteur Collection) was obtained freeze-dried (Lallemand SA) and was grown aerobically in MRS medium at $37^{\circ} \mathrm{C}$ with shaking for $24 \mathrm{~h}$ in 1-liter Erlenmeyer flasks (300 mL per flask). Cultures were inoculated with overnight precultures at $\mathrm{OD}_{550}$ of 0.1 .

\section{Transmission electron microscopy}

TEM observations were performed as follows: after two washing steps, bacterial cells were fixed, coloured using a $2.5 \%$ glutaraldehyde $+0.04 \%$ Ruthenium red solution in sodium cacodylate buffer $(0.1 \mathrm{M}, \mathrm{pH}=7.4)$ for at least $1 \mathrm{~h}$ at $4^{\circ} \mathrm{C}$, then embedded in $1.5 \%$ Low Melting Point Agarose and washed in sodium cacodylate buffer $(0.2 \mathrm{M})$ with $0.04 \%$ Ruthenium red. The post-fixation step was carried out in a mixture solution of osmium tetroxide $(2 \%)$ and $0.04 \%$ Ruthenium red in sodium cacodylate buffer $(0.2 \mathrm{M})$ for $2 \mathrm{~h}$ at room temperature. Cell dehydration was achieved through a series of graded ethanol solutions $\left(50^{\circ}, 70^{\circ}, 80^{\circ}, 10 \mathrm{~min}\right.$ each and then $\left.90^{\circ}, 95^{\circ} 2 \times 15 \mathrm{~min}\right)$. Infiltration and 
embedding were performed by incubating cells in several changes of LRWhite resin/ethanol mixtures, in which the concentration of resin was gradually increased to $100 \%\left(12 \mathrm{~h}\right.$ at $4^{\circ} \mathrm{C}$ in resin/ethanol $1: 2$, resin/ethanol $1: 1$, resin/ethanol $2: 1$ and pure resin). Cells were left to polymerize $24 \mathrm{~h}$ at $60^{\circ} \mathrm{C}$. Polymerized samples were sectioned in 90-nm-thick slices (Ultracut Reichert) and mounted on 150 mesh collodion-coated copper grids. Before observation, sections were stained with uranyl acetate and lead citrate. TEM observations were carried out on a Hitachi HU12A microscope, at an accelerating voltage of $75 \mathrm{kV}$.

\section{Preparation of CWPS}

Cells $(6 \mathrm{~g})$ were washed with water $(3 \mathrm{x})$, then suspended in water $(100 \mathrm{~mL})$ and autoclaved $\left(115^{\circ} \mathrm{C}\right.$, $20 \mathrm{~min}$ ). The mixture was cooled, and the cells collected by centrifugations. The supernatant was deproteinated by the addition of TCA to a final concentration of $5 \%$, dialyzed and freeze-dried. Further analysis established that it contained low amount of polysaccharides that were not further investigated.

Cell debris were further pre-extracted with $5 \% \mathrm{TCA}\left(48 \mathrm{~h}, 5^{\circ} \mathrm{C}\right.$ with stirring) and consecutively extracted at $100^{\circ} \mathrm{C}$ with $0.01 \mathrm{~N} \mathrm{HCl}(100 \mathrm{~mL}, 20 \mathrm{~min})$ and $0.1 \mathrm{~N} \mathrm{HCl}(70 \mathrm{~mL}, 20 \mathrm{~min})$ (Vinogradov et al. 2016). $\mathrm{HCl}$ extracts were pooled and deproteinated by addition of TCA, dialyzed and freezedried to give a crude extract. Cell Wall PolySaccharide (CWPS) was prepared from crude extracts after treatment with $48 \% \mathrm{HF}\left(4^{\circ} \mathrm{C}, 24 \mathrm{~h}\right)$, followed by fractionation of Sephadex G-50 and yield about 100 mg of polysaccharide.

\section{Analytical methods}

\section{Smith degradation}

CWPS $(30 \mathrm{mg})$ was dissolved in $0.05 \mathrm{M} \mathrm{NaIO}_{4}(6 \mathrm{~mL})$ and kept for $72 \mathrm{~h}$ in the dark at room temperature. To stop the reaction, 1,2-ethanediol $(0.5 \mathrm{~mL})$ was added, the solution was kept for $1 \mathrm{~h}$ and dialyzed for $24 \mathrm{~h}$. The resulting polyaldehyde was reduced with $\mathrm{NaBH}_{4}$ overnight. $\mathrm{NaBH}_{4}$ was 
destroyed with $\mathrm{AcOH}$, and the solution dialyzed and concentrated. The material was partially hydrolyzed by $\mathrm{AcOH}(2 \%)$ at $100^{\circ} \mathrm{C}$ for $2 \mathrm{~h}$ [20]. The mixture was cooled, freeze-dried and fractionated on a Biogel P2 column. The HMW fraction was collected, freeze-dried and used for structural analysis.

\section{Monosaccharide analysis}

Monosaccharides were detected as reduced and acetylated derivatives (alditol acetates). Polysaccharide samples $(0.2-1 \mathrm{mg})$ were hydrolyzed with $4 \mathrm{M} \mathrm{TFA}\left(110^{\circ} \mathrm{C}, 3 \mathrm{~h}\right)$, dried, taken in water with an addition of a few drops of $0.1 \mathrm{M} \mathrm{NH}_{4} \mathrm{OH}, \mathrm{pH}$, and reduced with $\mathrm{NaBH}_{4}$. The excess of $\mathrm{NaBH}_{4}$ was destroyed with $10 \% \mathrm{AcOH}$ in $\mathrm{MeOH}$, the solution was dried under the stream of nitrogen, dried twice more with addition of $10 \% \mathrm{AcOH}$ in $\mathrm{MeOH}(1 \mathrm{~mL})$ and twice $\mathrm{MeOH}(1 \mathrm{~mL})$. The residue was acetylated with $0.4 \mathrm{~mL} \mathrm{Ac} 2 \mathrm{O}-0.4 \mathrm{~mL}$ pyridine mixture for $1 \mathrm{~h}$ at $100^{\circ} \mathrm{C}$, dried under a stream of nitrogen with addition of toluene $(1 \mathrm{~mL})$ and analyzed by GC-MS.

\section{Determination of absolute configuration}

The absolute configuration of monosaccharides was determined by the procedure of Gerwig et al. [21]. The polysaccharide samples were hydrolysed with $4 \mathrm{M}$ TFA $\left(110{ }^{\circ} \mathrm{C}, 3 \mathrm{~h}\right)$, evaporated to dryness, taken in $\mathrm{MeOH}(0.5 \mathrm{~mL})$ and $\mathrm{N}$-acetylated with $\mathrm{Ac}_{2} \mathrm{O}(0.05 \mathrm{~mL})$ in presence of $\mathrm{Py}(0.01 \mathrm{~mL})$. The samples were then evaporated to dryness and subjected to butanolysis with (R)-(-)-sec-butanol $(0.2$ $\mathrm{mL})$ and acetyl chloride $(0.02 \mathrm{~mL})$ at $85^{\circ} \mathrm{C}$ for $16 \mathrm{~h}$. The samples were evaporated to dryness, acetylated $\left(0.2 \mathrm{~mL}\right.$ Py, $\left.0.2 \mathrm{~mL} \mathrm{Ac} 2 \mathrm{O}, 100^{\circ} \mathrm{C}, 1 \mathrm{~h}\right)$ and analyzed by GC-MS, as described above. Standards were prepared from D-Glc, D-Gal, D-GlcNAc and D-ManNAc with (R)-(-) and (S)-(+)-secbutanol.

\section{Methylation}


Methylation was performed by the Ciucanu-Kerek procedure [22] as modified by Read et al. [23]. The polysaccharide $(0.5-1 \mathrm{mg})$ was dissolved in $1 \mathrm{~mL}$ of dry DMSO. Freshly powdered $\mathrm{NaOH}$ (about 50 $\mathrm{mg}$ ) was added, the mixture stirred for $15 \mathrm{~min}$, then $0.2 \mathrm{~mL}$ of MeI was added and the mixture stirred for another $2 \mathrm{~h}$. The reaction was stopped by addition of $3 \mathrm{~mL}$ of $10 \%$ aq. $\mathrm{Na}_{2} \mathrm{~S}_{2} \mathrm{O}_{3}$. The permethylated product was extracted with $\mathrm{CHCl}_{3}(2 \times 2 \mathrm{~mL})$. The organic phase was washed with water $(5 \times 4 \mathrm{~mL})$, filtered through a cotton-plugged Pasteur pipette and evaporated. The product was hydrolyzed with 4 M TFA $\left(110^{\circ} \mathrm{C}, 3 \mathrm{~h}\right)$, dried, then reduced with $\mathrm{NaBD}_{4}$, converted into alditol acetates and analyzed by GC-MS. Methylated derivatives were identified using the Complex Carbohydrate Research Center partially methylated acetates (PMAA) database (www.ccrc.uga.edu/specdb/ms/pmaa/pframe.html) and by comparison with the authentic standards of methylation analysis of polysaccharides of various Lactococcus lactis strains.

\section{Chromatography}

Gel-permeation chromatography was performed on Sephadex G-50 (GE Health Care, 2.6 x $90 \mathrm{~cm}$ ) and BioGel P-2 (Biorad, $2.6 \times 80 \mathrm{~cm}$ ) columns, eluted with 0.1\% AcOH. Fractions were assayed for total [24] and aminosugars [25]. GC-MS was performed on a Trace GC ULTRA system (Thermo Scientific) equipped with a capillary column NMTR-5MS (30 $\mathrm{m} \times 0.25 \mathrm{~mm})$ using a temperature gradient of $170^{\circ} \mathrm{C}(3 \mathrm{~min}) \rightarrow 250^{\circ} \mathrm{C}$ at $5^{\circ} \mathrm{C} / \mathrm{min}$ and with a DSQ II MS detector.

\section{NMR spectroscopy}

After twice exchanges with ${ }^{2} \mathrm{H}_{2} \mathrm{O}$ (Eurisotop-Saclay France) sample was dissolved in pure $\mathrm{D}_{2} \mathrm{O}$. Experiments were recorded at various temperatures $(280,300,323 \mathrm{~K})$ but only spectra recorded at 300 $\mathrm{K}$ are shown. The pD was kept neutral. Experiments were recorded on Bruker ${ }^{\circledR}$ spectrometers at three different fields. 9.4 T, 18.8 T and 21.6 T were ${ }^{1} \mathrm{H}$ resonated at 400.33, 800.12 and 900.11 $\mathrm{MHz}$ whereas ${ }^{13} \mathrm{C}$ resonated at $100.2,200.3$ and $220.0 \mathrm{MHz}$ respectively. ${ }^{31} \mathrm{P}$ spectrum was recorded at $9.4 \mathrm{~T}$. Set of pulse programs used were extracted from Bruker® pulse program library where pulses (both hard and 
soft pulses and their powers) and delays were optimized for each experiment. For tocsy experiments 40, 60, 80 and $100 \mathrm{~ms}$ were used for mixing time in spectra recording.

\section{THP-1 and HEK293 cell culture}

Human pro-monocytic leukaemia THP-1 cells (ECACC $\mathrm{n}^{\circ}$ 88081201) were differentiated into macrophage-like cells with $20 \mathrm{nM}$ of phorbol-12-myristate-13-acetate (PMA) for $72 \mathrm{~h}$, in RPMI 1640 supplemented with 10\% FCS, $2 \mathrm{mM}$ L-glutamine, $2 \times 10^{-5} \mathrm{M} \beta$-mercaptoethanol and maintained under humidified atmosphere with $5 \% \mathrm{CO}_{2}$ at $37^{\circ} \mathrm{C}$ [26-27]. Cell viability was checked by trypan blue dye exclusion and by propidium iodide.

Human embryonic kidney (HEK) 293 cells, stably transfected with vectors encoding human hTLR2 or hTLR4/MD2/CD14, were purchased from InVivogen (Toulouse, France). Either HEK-Blue-hTLR4 cells and HEK-Blue-hTLR2 were obtained by co-transfection of HEK293 with both TLR-coreceptor genes and an inducible SEAP (secreted embryonic alkaline phosphatase) reporter gene. Cells were maintained in growth medium supplemented with HEK-blue selection according to the manufacturer's instructions. Stimulation of TLR2 or TLR4 dependent-pathways was followed by monitoring the activation of NF- $\kappa \mathrm{B}$ and $\mathrm{AP}-1$.

\section{Quantification of cytokine secretions by ELISA}

To investigate the effect of purified CWPS on the secretion of cytokines (TNF- $\alpha$, IL-1 $\beta$ ), differentiated THP-1 cells were incubated in RPMI 1640 medium supplemented with 2\% FCS and L-glutamine in presence of various concentrations of CWPS alone or with the synthetic lipopeptide $\mathrm{Pam}_{3} \mathrm{CSK}$, an agonist of TLR2. In some experiments, CWPS was pre-incubated with cells for $20 \mathrm{~h}$ before Pam ${ }_{3}$ CSK addition. Culture supernatants were collected after 8 -h or 24 -h cell stimulation and analyzed for the detection of cytokines by sandwich ELISA, according to the manufacturers' instructions (Ozyme S.A.). Cytokine concentrations were determined using standard curves obtained with recombinant human 
TNF- $\alpha$ and IL-1 $\beta$. Statistical significance was determined using the Student $t$ test, from three independent experiments performed in triplicate. Only values of $p<0.05$ were considered to be significant.

\section{HEK-blue-hTLR2 and HEK-blue-hTLR4 experiments}

Cells were seeded in 96-well plates at $5 \times 10^{4}$ cells/well for HEK-Blue-hTLR2 and at $2.5 \times 10^{4}$ cells/well for HEK-Blue-hTLR4. Transfected cells were then stimulated respectively, with either lipopeptide $\mathrm{Pam}_{3} \mathrm{CSK}_{4}(500 \mathrm{ng} / \mathrm{mL})$ or lipopolysaccharide (LPS E. coli O55B5 $50 \mathrm{ng} / \mathrm{mL}$ ), an agonist of TLR4 receptor. Increasing concentrations of CWPS were tested on cells, alone or in presence of $\mathrm{Pam}_{3} \mathrm{CSK}_{4}$ or LPS. After a 16 -h incubation at $37^{\circ} \mathrm{C}$, SEAP activity was determined using SEAP detection medium (QUANTI-Blue or HEK-blue detection), by measuring the OD at 620-655 nm. Three independent experiments were performed in triplicate.

\section{Flow cytometry analysis of ICAM-1 cell surface marker}

The expression level of the ICAM-1 (CD54) was determined after stimulation of both PMA-THP-1 or undifferentiated cells in presence of $50 \mu \mathrm{g} / \mathrm{mL}$ of CWPS, with or without $\mathrm{Pam}_{3} \mathrm{CSK}_{4}(0.5 \mu \mathrm{g} / \mathrm{mL})$, in RPMI 1640 supplemented with 2\% FCS and L-glutamine. After $24 \mathrm{~h}$ of incubation, expression of human ICAM-1 (CD54) was determined by flow cytometry. Briefly, 250,000 cells were pre-incubated for $20 \mathrm{~min}$ at $4^{\circ} \mathrm{C}$ with $\mathrm{Fc}$ receptor blocking reagent (Innovex Biosciences, USA) to decrease the nonspecific binding of IgG, washed twice, and incubated for 40 min with $10 \mu \mathrm{L}$ of PE-conjugated antiICAM-mouse monoclonal $\mathrm{IgG} 1 \kappa$ antibodies (BD Biosciences) in PBS containing $0.04 \% \mathrm{NaN}_{3}$ and 0.05\% BSA. PE-conjugated mouse isotype control IgG (BD Biosciences) was used as a negative control to evaluate the non-specific binding of IgG. After two washes, data were monitored on a flow cytofluorimeter (FACSCalibur, BD Biosciences) and analyzed with the CellQuest software (Mountain View, CA). Cells were gated for forward- and side-angle light scatters and the fluorescence channels 
were set on a logarithmic scale. Specific mean fluorescence intensity (MFI) was determined, from three independent experiments performed in triplicate, after subtraction of non-specific Ab binding.

\section{T84 cell culture}

The T84 human colon cell line (ECACC) was routinely maintained in Dulbecco's Modified Eagle's Medium (DMEM) / F-12 supplemented with 2 mM l-glutamine (Gibco, Fisher Scientific, Ilkirch, France), 10\% FBS (Sigma Aldrich,St Quentin Fallavier, France). Cells were seeded at high density in $75 \mathrm{~cm}^{2}$ polystyrene tissue culture flasks (Fisher scientific) and maintained in humidified incubator with $5 \% \mathrm{CO}_{2}$ at $37^{\circ} \mathrm{C}$. To generate polarized $\mathrm{T} 84$ cell monolayers, approximately $4 \times 10^{5}$ cells were seeded into the apical chamber of polystyrene Transwell permeable support cell culture inserts $\left(0.33 \mathrm{~cm}^{2}\right.$, $0.4 \mu \mathrm{m}$ pore size; Corning, Sigma Aldrich). Cell culture medium in both the apical and basolateral chambers was changed every $48 \mathrm{~h}$ and cells were allowed to grow for 7 days.

\section{Electrical impedance measurements}

The TEER of filter-grown T84-cell monolayers was measured using the cellZScope ${ }^{\circledR}$ system (nanoAnalytics, Germany). The baseline TEER value was around $1000 \Omega . \mathrm{cm}^{2}$ before cells were challenged with CWPS and/or cytokines. A mixture of TNF- $\alpha$ and IFN- $\gamma$ (both $10 \mathrm{ng} / \mathrm{mL}$, Clinisciences) was added after a 24-h pretreatment period with $200 \mu \mathrm{g} / \mathrm{mL}$ CWPS (preventive effect). The concentration of cytokines was based on effective values previously described in the literature [28]. TNF- $\alpha / \mathrm{IFN}-\gamma$ was added to the basal chamber whereas CWPS was administrated to the apical compartment only. The TEER variation was continuously monitored over a total incubation time of $54 \mathrm{~h}$ (i.e. a 24-h CWPS treatment followed by a 30-h CWPS co-exposure with TNF- $\alpha / \mathrm{IFN}-\gamma$ ). The mean values of TEER of the different treated cell monolayers were then normalized by the mean of the control monolayers in the same experiment. 


\section{Results}

\section{Extraction and purification of CWPS}

TEM observations of L. farciminis cell surface showed a presence of an external "fuzzy" layer, which may play a role in bacteria-host interaction in the gut (Fig. 1). In order to extract potential polysaccharides from this layer, we first applied a mild extraction procedure, elaborated for isolating capsular polysaccharides from Gram-positive bacteria [29]. This extraction protocol yielded low quantities of a polysaccharide fraction containing D-GlcNAc, D-ManNAc, D-Glc and D-Gal. ${ }^{1} \mathrm{H}$ NMR analysis of this fraction demonstrated that its structure was identical to the CWPS (see below). Thus, its structural features were not further investigated.

Cell debris were further extracted consecutively with cold 5\% TCA, hot $0.01 \mathrm{~N}$ and $0.1 \mathrm{~N} \mathrm{HCl}$. This methodology was initially developed for extraction of rhamnose-glucose polymers (RGP) from $S$. mutants serotype $d$ [30], and then was successfully used for isolating of rhamnans from Lactococcus lactis strains [31]. $\mathrm{HCl}$ extractions afforded high yield of a CWPS, identical to the soluble polysaccharide fraction. This allowed us to assume that the major PS of L. farciminis was a CWPS strongly linked to the cell wall.

Native CWPS showed the presence of phosphate groups on NMR (data not shown), and was retained on the anion-exchange column. However, after treatment with $48 \%$ HF, the CWPS became neutral. The treatment did not lead to any change in monosaccharide composition and the aspect of the ${ }^{1} \mathrm{H}-$ NMR spectrum. We therefore presumed the presence of an anchor, linked to the polysaccharide by a phospho-diester bond. The HF-treated CWPS was further used for structural analysis (referred to as native CWPS).

\section{Structural analysis of $L$. farciminis CWPS}


Monosaccharide analysis by GC-FID and GC-MS established the presence of Glc, Gal, GlcNAc, and ManNAc in the in the approximate ratio 5/0.9/3/1. The absolute configuration analysis using (sec)butyl-glycoside derivatives [21] confirmed that all monosaccharides had D-configurations. The 1D1H proton spectra of native CWPS (Fig. 2A) showed a complex anomeric signals pattern that suggested the occurrence of a polydisperse high molecular weight (HMW) polysaccharide. (HMWP) The ${ }^{1} \mathrm{H}-{ }^{13} \mathrm{C}$ HSCQ did not show any $O$-acetylation; however, multiple signals resonating between 2.2 and 2.0 ppm indicated the presence of $N$-acetyl groups (Fig. 2A). Methylation analysis showed the presence of terminal Glcp, terminal Gal $p$ in a ratio 10/1 as well as minor amounts of 2-, 4-, and 6- linked hexoseand several substituted HexN residues (data not shown). The results of methylation analysis indicated that HMWP had a complex branched structure, probably substituted by terminal D-Gle $p$ residues and D-Galp-containing oligosaccharides.

\section{Structural analysis of CWPS backbone}

In order to simplify the structure of CWPS and proceed to its structural analysis, we first removed the side chains that substitute the polysaccharidic backbone by subjecting the polysaccharide to periodate oxidation of diols, using Smith degradation [32]. Gel-filtration chromatography of the resulting product showed a significant depolymerisation. Monosaccharide analysis of the resulting HMW fraction showed only GlcNAc and ManNAc in an approximate ratio 3:1. The resulting $1 \mathrm{D}{ }^{1} \mathrm{H}-\mathrm{NMR}$ spectrum was considerably simplified compared to the native polysaccharide (Fig. 2B). Indeed, the spectrum contained three major anomeric protons, tentatively assigned to $\alpha \operatorname{Glc} p \operatorname{NAc}(\mathbf{A}, \delta=5.23)$, $\beta \operatorname{Man} p \operatorname{NAc}(\mathbf{B}, \delta=4.89)$ and $\beta \operatorname{Glc} p \operatorname{NAc}(\mathbf{C}, \delta=4.54)$. Their configurations were confirmed by the identification of their respective spin system on $2 \mathrm{D}{ }^{1} \mathrm{H}-{ }^{1} \mathrm{H}$ TOCSY and ${ }^{1} \mathrm{H}-{ }^{13} \mathrm{C}$ HSQC experiments

(Fig. 3). Then, ${ }^{1} \mathrm{H}$ and ${ }^{13} \mathrm{C}$ spectra of the product of Smith degradation were fully assigned (Table 1). Observation of deshielded C4 carbons of $\beta$-ManNAc (B) and $\beta$-GlcNAc (C) at $\delta 74.9$ and 80.2 respectively established that $\mathbf{B}$ and $\mathbf{C}$ residues are both substituted in $\mathbf{C} 4$ positions (Table 1 and Fig. 3). Similarly, the observation of deshielded C6 carbon of $\alpha$-GlcNAc (A) at $\delta 69.4$ established that A 
residue was substituted in C6 position. The sequences were then established by a combination of 300 ms-ROESY, 200 ms-NOESY and ${ }^{1} \mathrm{H}-{ }^{13} \mathrm{C}$ HMBC experiments as a linear trisaccharide repeat unit (6A1-4B1-4C1-). It was therefore shown that the product of Smith degradation of HMW-PS of $L$. farciminis was composed of linear trisaccharide repeating units having a structure shown in Fig. 2B. The sequence was further confirmed by mass spectrometry. MALDI-TOF MS analysis of the Smith degradation product showed a complex pattern of $[\mathrm{M}+\mathrm{Na}]^{+}$signals consistent with a $[\mathrm{HexNAc}]_{\mathrm{m}}-\mathrm{Gro}$ composition where Gro is a residue of glycerol formed at the reducing end of the molecule due to Smith degradation of a non-branched 6-linked HexNAc of the main chain, with m varying from 4 to 15 (Fig. 4A). Two series of compounds with $\mathrm{m} / \mathrm{z}$ increments of 609 mass units were identified as [HexNAc $]_{\mathrm{n}}$-Gro at $m / z 1333(\mathrm{n}=1), 1942(\mathrm{n}=2), 2552(\mathrm{n}=3), 3161(\mathrm{n}=4)$ and $3770(\mathrm{n}=5)$ and as [HexNAc $]_{\mathrm{p}}-\mathrm{HexNAc}_{2}$ Gro at $m / z 1130(\mathrm{p}=1), 1739(\mathrm{n}=2), 2349(\mathrm{n}=3), 2958(\mathrm{n}=4)$ and $3567(\mathrm{n}=5)$. MALDI-TOF/TOF MS/MS analysis of individual products confirmed that they were all made of linear stretches of HexNAc with a Gro at the terminal position. As an example, fragmentation pattern of the $[\mathrm{M}+\mathrm{Na}]^{+}$signal at $\mathrm{m} / \mathrm{z} 1739.8$ showed a complete set of $\mathrm{B}$ fragment ions generated by the loss of the terminal HexNAc-Gro motif and an almost complete set of Y fragment ions generated by consecutive losses of HexNAc residues (Fig. 4B). Thus, NMR and mass spectrometry data established that $L$. farciminis CWPS backbone was composed of linear trisaccharide repeating units containing an $\alpha$ Glc $p$ NAc, $\quad \beta$-Glc $p$ NAc $\quad$ and $\quad$ a $\quad \beta$-Man $p$ NAc $\quad$ residue $\quad$ (Fig. 3 ): $[\rightarrow 6 \alpha \mathrm{Glc} p \mathrm{NAc} 1 \rightarrow 4 \beta \mathrm{Man} p \mathrm{NAc} 1 \rightarrow 4 \beta \mathrm{Glc} p \mathrm{NAc} 1 \rightarrow]$

\section{Structural analysis of native CWPS}

As already mentioned, NMR spectrum of intact CWPS was extremely complex, supposedly because of the polydisperse nature of the polysaccharide. Following the identification of the polysaccharide backbone, we recorded on intact CWP a set of NMR spectra including TOCSY 2D-homonuclear ${ }^{1} \mathrm{H}-$ ${ }^{1} \mathrm{H}$ with various mixing times, 300ms NOESY spectra, edited ${ }^{1} \mathrm{H}_{-}{ }^{13} \mathrm{C}$ HSQC and ${ }^{1} \mathrm{H}-{ }^{13} \mathrm{C}$ HMBC spectra, in order to establish the carbohydrate sequence of the native polysaccharide. In addition, 1D 
${ }^{31} \mathrm{P}$ and $2 \mathrm{D}{ }^{1} \mathrm{H}-{ }^{31} \mathrm{P}$ HSQC NMR spectra indicated the presence a phosphate group in the polysaccharide. All identified signal chemical shifts are shown in Table 2.

We confidently observed and identified eighteen anomeric protons including five highly downfield shifted protons up to $5.81 \mathrm{ppm}(\mathbf{a}, \mathbf{a}, \mathbf{b}, \mathbf{c}$, and d) (Fig. 5). All other protons resonated below $5.3 \mathrm{ppm}$ (e to $\mathbf{m}$ '). All carbons resonated between 91 and $103 \mathrm{ppm}$ confirming the anomeric position of these atoms. Analysis of both heteronuclear direct constant ${ }^{1} J_{\mathrm{H}, \mathrm{C}}$ (Table 2) on ${ }^{1} \mathrm{H}-{ }^{13} \mathrm{C}$ undecoupled HSQC spectrum and homonuclear vicinal coupling constant $\left({ }^{3} J_{\mathrm{H}, \mathrm{H}}\right)$ on COSY and TOCSY spectra indicated four different monosaccharide configurations all with pyranose conformation. According to Koerner et al. [33], we identified $\alpha$-Glucopyranose cycle (a, a', b, c, d, e, f, $\mathbf{g}, \mathbf{g}, \mathbf{h}$ and $\mathbf{j}), \beta$-Mannopyranose $\left(\mathbf{k}, \mathbf{k}^{\prime}\right), \beta$-Glucopyranose (1, m, m') and $\alpha$-Galactopyranose (i, i') configurations. No furanose was observed, as confirmed by HSQC experiments. The b, c, e, f, $\mathbf{k}, \mathbf{l}$ and $\mathbf{m}$ units were identified as $N$ Acetyl-osamines according to the chemical shift of their carbon 2 between 53 to 58 ppm on the 2D edited ${ }^{1} \mathrm{H}-{ }^{13} \mathrm{C}$ HSQC spectrum (Fig. 6). The HMBC experiment allowed us to associate acetyl group signals at $\delta$ 2.06-2.09/23.3-23.7 with these osamines except signal a' that was associated to a glucosamine residue since no ${ }^{3} J_{\mathrm{H}, \mathrm{C}}$ could be observed between $\mathrm{H} 2$ and ${ }^{13} \mathrm{C}$ of a ceton group. Thus, $\mathbf{b}$, c, e and $\mathbf{f}$ residues were identified as $\alpha-N$-Acetyl glucosamine ( $\alpha \operatorname{Glc} p N A c)$, $\mathbf{k}$ and $\mathbf{k}^{\prime}$ as $\beta$ - $N$-Acetylmannosamine residues and $\mathbf{l}, \mathbf{m}$ and $\mathbf{m}$ ' to $\beta$ - $N$-Acetyl-glucosamine, in agreement with results from monosaccharides composition analysis. Other monosaccharides were identified as neutral sugars and correspond to $\alpha \operatorname{Glc} p\left(\mathbf{a}, \mathbf{d}, \mathbf{g}, \mathbf{g}^{\prime}, \mathbf{h}, \mathbf{j}\right)$ and $\alpha \operatorname{Gal} p\left(\mathbf{i}, \mathbf{i}^{\prime}\right)$ residues again in agreement with results from monosaccharides composition analysis.

We then established the polysaccharide sequence using ${ }^{1} \mathrm{H}-{ }^{1} \mathrm{H}$ NOESY and ${ }^{1} \mathrm{H}-{ }^{13} \mathrm{C}$ HMBC experiments. The main identified dipolar nOe contacts and identified vicinal heteronuclear constants $\left({ }^{3} J_{\mathrm{H}, \mathrm{C}}\right)$ were summarized in Table 3 . The main backbone chain was identified having $-\mathbf{m}(6) \mathbf{e}(4) \mathbf{k}(4)-$ sequence corresponding to the unbranched $[\rightarrow 6 \alpha \text { Glc } p \text { NAc1 } \rightarrow 4 \beta \text { Man } p N A c 1 \rightarrow 4 \beta \text { Glc } p \text { NAc1 }]_{\mathrm{n}}$ chain described in periodate oxidation product. Indeed we observed strong vicinal heteronuclear constant 
$\left({ }^{3} J_{\mathrm{H}, \mathrm{C}}\right)$ on $\mathrm{HMBC}$ spectrum $\mathrm{H} 1 \mathbf{e} \rightarrow \mathrm{C} 4 \mathbf{k}$ at $\delta 5.22 / 75.1, \mathrm{H} 1 \mathbf{k} \rightarrow \mathrm{C} 4 \mathbf{m}$ at $\delta 4.89 / 80.5$ and $\mathrm{H} 1 \mathbf{m} \rightarrow \mathrm{C} 6 \mathbf{e}$ at $\delta$

4.56/69.7. This sequence was confirmed by the observation of strong ${ }^{1} \mathrm{H}-{ }^{1} \mathrm{H}$ nOe contacts $\mathrm{H} 1 \mathrm{e} \rightarrow \mathrm{H} 3 \mathbf{k}$ at 5.22/4.06, H1 $\mathbf{k} \rightarrow \mathrm{H} 4 \mathbf{m}$ at 4.90/3.71 $\mathrm{ppm}, \mathrm{H} 1 \mathbf{m} \rightarrow \mathrm{H} 6,6$ 'e at 4.56/4.11ppm and of ${ }^{3} J_{\mathrm{H}, \mathrm{C}}$ connections $\mathrm{H} 1 \mathbf{k} \rightarrow \mathrm{C} 4 \mathrm{~m}$ and $\mathrm{H} 1 \mathbf{m} \rightarrow \mathrm{C} 6 \mathbf{e}$. In addition to the $\mathbf{e}, \mathbf{k}$ and $\mathbf{m}$ spin systems associated to the unbranched trisaccharide unit, we observed on HSQC and TOCSY spectra multiple signals associated to branched versions of the trisaccharide core in $\mathrm{C} 3$ position of $\beta$ Man $p$ NAc unit ( $k$ and $\mathbf{k}^{\prime}$ ) substituted by different side chains and in $\mathrm{C} 4$ position of $\alpha \mathrm{Glc} p \mathrm{NAc}(\mathbf{c})$. The heterogenous substitution pattern of $\mathbf{k}$ induced chemical shift dispersion not only of $\mathbf{k}\left(\mathbf{k}, \mathbf{k}^{\prime}\right)$, but also of adjacent signals $\mathbf{m}\left(\mathbf{m}, \mathbf{m}^{\prime}\right)$ and $\mathbf{e}(\mathbf{e}, \mathbf{b}, \mathbf{c})$ depending on up and down substitution next to the corresponding unit. As deduced from their respective spin systems, the unit $\mathbf{k}$ was exclusively substituted in $\mathrm{C} 4$ position $(\mathrm{C} 3 / \mathrm{C} 4$ at $\delta 74.0 / 75.1)$ whereas $\mathbf{k}^{\prime}(\mathrm{C} 3 / \mathrm{C} 4$ at $\delta 81.3 / 78.1)$ was further branched in $\mathrm{C} 3$ position. Similarly, whereas $\mathbf{e}$ and $\mathbf{b}$ units are exclusively substituted in C6 position by $\mathbf{m}, \mathbf{c}$ unit is further substituted in $\mathrm{C} 4$ position (C4 at 81.2 ppm). Finally, $\mathbf{m}$ and $\mathbf{m}$ ' were both exclusively substituted in C4 position. The residues k', m' and $\mathbf{b} / \mathbf{c}$ showed similar ${ }^{3} J_{\mathrm{H}, \mathrm{C}}$ connectivity and ${ }^{1} \mathrm{H}-{ }^{1} \mathrm{H}$ nOe contacts patterns than those observed for $\mathbf{k}$, m and e respectively, which confirmed that theses residues are all part of the $[\rightarrow 6 \alpha \text { Glc } p \text { NAc } 1 \rightarrow 4 \beta \text { Man } p \text { NAc1 } 1 \rightarrow 4 \beta \text { Glc } p \text { NAc1 }]_{\mathrm{n}}$ substituted backbone chain. However, because of the proximity of chemical shifts and heterogeneity of $\mathbf{k}$ and $\mathbf{k}$ ' substitutions, it was difficult to clearly distinguish the connections between individual residues. Then, the minor $\mathbf{f}$ and $\mathbf{l}$ signals were identified as the $\alpha$ - and $\beta$ GlcpNAc residues in free terminal reducing position according to their spin systems, which suggests that the polysaccharide chain was partially hydrolysed during the purification procedure.

Finally, we identified the polysaccharide side chains by observing HMBC et nOe connections of remaining signals onto the polysaccharide backbone. The $\beta$ Man $p$ NAc residue was shown to be substituted in $\mathrm{C} 3$ position by three different side chains. First, the terminal $\alpha$ Glc $p$ residue $\mathbf{h}$ was shown to substitute the $\mathrm{C} 3$ position of 3,4-substituted $\beta$ DMan $p$ NAc residue $\mathbf{k}^{\prime}$ of the backbone owing to nOe $\mathrm{H} 1 \mathbf{h} \rightarrow \mathrm{H} 3 \mathbf{k}^{\prime}$ connection. Then, we identified a disaccharide side chains substituting the $\beta$ DMan $p$ NAc 
of the backbone also in $\mathrm{C} 3$ position. This disaccharide was identified as $\alpha \mathrm{Glc} p \mathrm{NH}_{2}(1-2) \alpha \mathrm{Glc} p$ (a' 12g). Spin systems typified a' as terminal $\alpha \mathrm{Glc} p \mathrm{NH}_{2}$ residue and $\mathbf{g}$ as 2-substituted $\alpha \mathrm{Glc} p$ residue (C2 $\mathbf{a}^{\prime}$ at $\left.81 \mathrm{ppm}\right)$. The $\mathrm{H} 1 \mathbf{a}^{\prime} \rightarrow \mathrm{H} 1 \mathbf{g} \rightarrow \mathrm{H} 3 \mathbf{k}^{\prime}$ nOe contacts and the ${ }^{3} J_{\mathrm{H}, \mathrm{C}}$ coupling $\mathrm{H} 1 \mathbf{g} \rightarrow \mathrm{C} 3 \mathbf{k}$ ' on $\mathrm{HMBC}$ experiment established the $\alpha \operatorname{Glc} p \mathrm{NH}_{2}(1-2) \alpha \operatorname{Glc} p(1-3) \beta D M a n p N A c$ sequence. Finally a trisaccharide $\alpha \operatorname{Gal} p(1-6) \alpha \operatorname{Glc} p(1-4) \alpha \operatorname{Gal} p(\mathbf{i} 1-6 \mathbf{j} 1-4 \mathbf{i}$ ') sequence was shown to also substitute the $\beta$ DMan $p$ Ac residue of the backbone in $\mathrm{C} 3$ position. Indeed, ${ }^{3} J_{\mathrm{H}, \mathrm{C}}$ coupling $\mathrm{H} 1 \mathbf{i} \rightarrow \mathrm{C} 6 \mathbf{j}$ observed on $\mathrm{HMBC}$ spectrum at 4.98/67.1 ppm and strong $\mathrm{H} 1 \mathbf{i} \rightarrow \mathrm{H} 6 / \mathrm{H} 6$ 'j nOe effects demonstrated that terminal $\alpha \mathrm{Gal} p \mathbf{i}$ substituted $\alpha$ Glcp $\mathbf{j}$ in C6 position. Then ${ }^{3} J_{\mathrm{H}, \mathrm{C}}$ coupling $\mathrm{H} 1 \mathbf{j} \rightarrow \mathrm{C} 4 \mathbf{i}{ }^{\prime}$ at $4.93 / 80.8 \mathrm{ppm}$ and strong nOe contact $\mathrm{H} 1 \mathbf{j} \rightarrow \mathrm{H} 4 \mathbf{i}$ ' unit showed that $\alpha \mathrm{Glc} p$ residue $\mathbf{j}$ substituted $\alpha \mathrm{Gal} p$ residue $\mathbf{i}$ ' in $\mathrm{C} 4$ position. The linkage of $\alpha \mathrm{Gal} p(1-6) \alpha \mathrm{Glc} p(1-4) \alpha \mathrm{Gal} p$ sequence to the backbone chain was established by observing ${ }^{3} J_{\mathrm{H}, \mathrm{C}}$ $\mathrm{H} 1 \mathbf{i}^{\prime} \rightarrow \mathrm{C} 3 \mathbf{k}^{\prime}$ connection on HMBC spectrum. The $\alpha$ Glc $p$ NAc residue was shown to be substituted in C4 position by a disaccharide side chain $\alpha \operatorname{Glc} p(1-2) \alpha \operatorname{Glc} p\left(\mathbf{g}^{\prime} 1-2 \mathbf{d}\right)$. The ${ }^{3} J_{\mathrm{H}, \mathrm{C}}$ connections $\mathrm{H} 1 \mathbf{g}^{\prime} \rightarrow \mathrm{C} 2 \mathbf{d}$ and $\mathrm{H} 1 \mathbf{d} \rightarrow \mathrm{C} 4 \mathbf{c}$ established the $\alpha \operatorname{Glc} p(1-2) \alpha \operatorname{Glc} p(1-3) \alpha \operatorname{Glc} p$ NAc sequence.

Altogether, the analysis of individual chemical shifts, ${ }^{3} J_{\mathrm{H}, \mathrm{C}}$ connections and ${ }^{1} \mathrm{H},{ }^{1} \mathrm{H}$ nOe contacts enabled us to confidently identify at least four side chains, $\alpha \mathrm{Glc} p, \alpha \mathrm{Glc} p \mathrm{NH}_{2}(1-2) \alpha \mathrm{Glc} p, \alpha \mathrm{Gal} p(1-$ 6) $\alpha \mathrm{Glc} p(1-4) \alpha \mathrm{Gal} p$ and $\alpha \operatorname{Glc} p(1-2) \alpha \mathrm{Glc} p$ that can substitute the polysaccharide backbone $[\rightarrow 6 \alpha \text { Glc } p \text { NAc } 1 \rightarrow 4 \beta \text { Man } p \text { NAc1 } \rightarrow 4 \beta G l c p N A c 1]_{n}$ either in $\mathrm{C} 3$ position of $\beta$ Man $p$ NAc residue for the three first ones or in $\mathrm{C} 4$ position of $\alpha \mathrm{Glc} p \mathrm{NAc}$ residue for the last one. All our observations concurred toward the absence of a clear repetition unit, but rather on a sub-stoichiometric substitution of C3 and C4 positions of the $\beta$ Man $p$ NAc and $\alpha$ Glc $p$ NAc residues along the polysaccharide backbone. In addition, some structural features remained unresolved. In particular, $\alpha \mathrm{Glc} p \mathrm{NH}_{2}$ (a') residue appears to be further substituted in $\mathrm{C} 3$ position as indicated by its $\mathrm{C} 3$ downfield chemical shift (77.9 ppm), but the substituting monosaccharide could not be identified. Finally, a residue was identified as a phosphorylated $\alpha \mathrm{Glc} p-\mathrm{PO}_{4}$ linked to $\mathrm{O}-\mathrm{CH}_{2}-$ group as proved by ${ }^{1} \mathrm{H}^{3}{ }^{31} \mathrm{P}$ HSQC experiment (data not 
shown), but we could not establish if the resulting $\alpha \mathrm{Glcp}-\mathrm{PO}_{4}-\mathrm{CH}_{2}$ - motif was associated or not to the main backbone chain.

\section{Modulatory effects of CWPS on the secretion of inflammatory cytokines and cell surface antigen expression in macrophage-like THP-1 cells}

We investigated the effect of CWPS on the production of inflammatory cytokines by PMA-treated THP-1 cells. As shown in Fig. 7, exposure of cells to CWPS, even at high concentration, failed to induce the secretion of TNF- $\alpha$ (Fig. 7A) and IL1- $\beta$ (Fig. 7B), whereas these cytokines were highly upregulated by $\mathrm{Pam}_{3} \mathrm{CSK}$ lipopeptide, known as a powerful agonist of TLR2 [34]. Furthermore, in order to test the potential anti-inflammatory effect of CWPS on PMA-THP1, co-stimulation studies of $\mathrm{Pam}_{3} \mathrm{CSK}$ with the polysaccharide were performed. When CWPS was added simultaneously to $\mathrm{Pam}_{3} \mathrm{CSK}$ or pre-incubated for $20 \mathrm{~h}$ with cells before activation by $\mathrm{Pam}_{3} \mathrm{CSK}$, the lipopeptide-induced production of cytokines was not significant decreased $(p>0.05)$ (Fig. 7C, D), which established that CWPS does not exhibit anti-inflammatory activity in vitro.

Different microbial components and cytokines regulate the macrophage cell activation process by interfering with the expression of cell surface antigens [35-36]. To extend our study on the immunomodulatory activity of CWPS, we analyzed by flow cytometry the ability of CWPS to modulate the ICAM-1 (Intercellular adhesion molecule) expression, at the surface of both monocyte and macrophage-like THP-1 cells, by using PE-conjugated anti-ICAM1 antibody. ICAM-1 is involved in leukocytes adhesion and T lymphocytes activation, via $\alpha 1 / \beta 2$ integrin dependent-interaction [3738]. As shown in Fig. 8, ICAM-1 was weakly expressed on monocyte THP-1 but increased after differentiation of THP-1 into macrophages by PMA. Pam ${ }_{3}$ CSK alone elicited ICAM-1 at cell surface of both THP1 and PMA-THP-1, compared to unstimulated cells, whereas CWPS alone was unable to trigger antigen expression. Furthermore, CWPS failed to down-regulate the ICAM-1 production induced by $\mathrm{Pam}_{3} \mathrm{CSK}$, as illustrated by overlapping of peaks 4 and 3 . 
Taken together, these results reveal that CWPS does not exert any pro- or anti-inflammatory properties on macrophage-like THP-1 cells.

\section{Activation of transfected hTLR2- and hTLR4-HEK-blue cells in presence of CWPS}

Over the last decade, TLR- reporter cell lines have extensively been used to screen the properties of microbial components in immune responses. Thus, we evaluated whether CWPS may regulate the activation of HEK-blue cells transfected with human TLR2 or TLR4 receptors, by monitoring the stimulation of NF-אB and AP-1, pathways, through an inducible SEAP (secreted embryonic alkaline phosphatase) reporter gene. As shown in Fig. 9, Pam ${ }_{3}$ CSK and LPS TLR agonists induce activation of hTLR2 or hTLR4 respectively in HEK-blue cells, as established by measuring SEAP in medium. In contrast to $\mathrm{Pam}_{3} \mathrm{CSK}$ and LPS, CWPS exhibited no eliciting activity on transfected hTLR2- or hTLR4HEK blue cells (Fig. 9). Moreover, CWPS did not inhibit the NF-אB and AP-1 signaling pathways induced by Pam $_{3}$ CSK and by LPS in TLR-transfected HEK-blue cells ( $p>0.05$ vs Pam ${ }_{3}$ CSKor LPSstimulated). These results indicate that CWPS cannot modulate TLR2 and TLR4 dependent cell signaling pathways of in transfected HEK-cells.

\section{Modulatory effects of CWPS on the epithelial barrier integrity in T84 intestinal epithelial cells}

Finally, we investigated the modulatory effects of CWPS on the epithelial barrier function in T84 cells, under basal conditions or after a pro-inflammatory cytokine challenge. As shown in Fig. 10, untreated T84 monolayers maintained TEER levels over the time-course of the experiment whereas monolayers challenged with the pro-inflammatory TNF- $\alpha$ and IFN- $\gamma$ cytokines demonstrated a continuous and significant decrease in TEER ( $p<0.01$ vs untreated at $46 \mathrm{~h}$ and above). This cytokine-mediated epithelium impairment was not prevented when the monolayers were pre-treated with CWPS. In addition, CWPS itself had no effect on the integrity of the epithelial barrier (i.e. neither disruption nor 
strengthening) since comparable TEER values were observed during the overall tested time period in comparison with control conditions (Fig. 10).

\section{Discussion}

The role of polysaccharides isolated from probiotic lactobacilli is of growing interest, notably through their ability to interact with the host, even though the relationship between their chemical structure and function(s) is far from being completely understood $[10,39]$. In the present study, we characterized the chemical structure of a cell wall polysaccharide isolated from the probiotic bacterium L. farciminis CIP 103136, and evaluated its biological role in vitro, including immunostimulatory responses and modulatory properties on the intestinal epithelial barrier integrity. First, we comprehensively characterized the structures of polysaccharides and identified a major cell-wall linked PS (thereafter termed CWPS) which could not be released by TCA treatment, a standard method used for extraction of cell wall TAs from Gram positive bacteria. We extracted it by consecutive treatment with hot 0.01 $\mathrm{N}$ and $0.1 \mathrm{~N} \mathrm{HCl}$. The backbone of CWPS was composed of a linear trisaccharide repeating unit, containing a 6-linked $\alpha$-GlcNAc, and 4-linked $\beta$-GlcNAc and $\beta$-ManNAc residues with the following sequence $[\rightarrow 6 \mathrm{D}-\alpha \mathrm{Glc} p \mathrm{NAc} 1 \rightarrow 4 \mathrm{D}-\beta \mathrm{Man} p \mathrm{NAc} 1 \rightarrow 4 \mathrm{D}-\beta \mathrm{Gl} p \mathrm{NAc} 1 \rightarrow]$. The backbone was substituted with single residues of D- $\alpha \mathrm{Glc} p$ and short oligosaccharides containing D- $\alpha \mathrm{Glc} p$, D- $\alpha \mathrm{Gal} p$ and D$\alpha \mathrm{Glc} p \mathrm{NH}_{2}$. Thanks to the almost quantitative substitution of the 6-linked GlcNAc residue, the PS was recovered in the polymeric form after Smith degradation, which facilitated its structural elucidation. The polymeric chain was partially cleaved at the sites of 6-linked GlcNAc residues without site substitution, leading to the formation of Gro residue at the reducing end of the polymeric chains. Intriguingly, the PS backbone is reminiscent to those isolated from Bacillus species including pathogenic B. anthracis and B. cereus strains [40-42] but was differently decorated: in Bacillus species, the backbone was substituted by single $\alpha \mathrm{Gal}$ and $\beta \mathrm{Gal}$ residues while in L. farciminis, the backbone may be substituted by a number of decorations including single $\alpha$ Glc and $\alpha$ GlcNAc residues or short oligosaccharides. This structure is completely different from those so far described in other species of 
lactobacilli. In particular, L. casei and paracasei strains were shown to synthesize a wide variety of cell wall associated polysaccharides with rhamnose-rich backbones including

$\rightarrow 3 \alpha$ LRha $1 \rightarrow 3 \alpha$ LRha $1 \rightarrow 3 \beta$ DGalNAc $1 \rightarrow 2 \alpha$ LRha $1 \rightarrow 2 \alpha$ LRha $\rightarrow$

$\rightarrow 2 \alpha \mathrm{Rha} 1 \rightarrow 3 \beta \mathrm{GlcNAc} 1 \rightarrow 3 \alpha \mathrm{Rha} 1 \rightarrow 3 \beta \mathrm{GalNAc} 1 \rightarrow$

and

$\rightarrow 2 \alpha \mathrm{Rha1} \rightarrow 2 \alpha \mathrm{Rha} 1 \rightarrow 3 \alpha \mathrm{Rha} 1 \rightarrow 3 \beta \mathrm{GalNAc} 1 \rightarrow[44]$ whereas $L$. heveticus strains were shown to synthesize mixed rhamnose- and/or galactose-rich backbones including $\rightarrow 3 \beta$ GlcNAc6PEtN1 $\rightarrow 3 \alpha$ Gall $\rightarrow 4 \beta$ Rha1 $\rightarrow 4 \beta$ Glc $\rightarrow \quad$ and $\rightarrow 6 \beta \mathrm{Gal} f 1 \rightarrow 3 \alpha \mathrm{Gall} \rightarrow 2 \beta \mathrm{Gal} f 1 \rightarrow 3 \alpha \mathrm{Gal} 1 \rightarrow 4 \alpha \mathrm{Gal} 1 \rightarrow 2 \beta \mathrm{Gal} f \rightarrow[45]$. To our knowledge, this is the first time that the presence of a hexosamine-rich polysaccharide backbone has been described for lactobacilli polysaccharides, which makes the structure of L. farciminis CWPS unique among lactobacilli. The structural similarity of this polysaccharide with the ones observed in a number of Bacillus species is very intriguing and its origin should be further investigated.

The ability of PS isolated from lactobacilli to trigger immunomodulatory responses has been previously depicted, however with strong emphasis on exopolysaccharides (EPS) and not cell-wall associated ones [46-52]. Furthermore, the broad structural diversity and accessibility of bacterial PSs may influence the nature of recognition by the immune system. Based on its novel and specific chemical structure, we thus carried out an in vitro immunological characterization of CWPS, considering first its ability to modulate activation of the human THP-1 cell line. Indeed, monocytic THP-1 cells, which may be differentiated into macrophages by PMA, are extensively used as model for screening immuno-modulatory effects of bacteria-derived components, which interact with both lectinic receptors and TLR-dependent pathways [53]. Then, we explored the CWPS ability to regulate the activation of HEK-blue cells transfected with human TLR2 or TLR4 receptors. In all cell models tested, CWPS was immunologically silent. Indeed, CWPS failed to induce the secretion of cytokines in macrophages and displayed no altered signaling capacities when applied to TLR2- or TLR4expressing HEK cells. This is in line with the results of Górska et al. [9] who reported that PS isolated 
from Lactobacillus rhamnosus LOCK 0900 neither induced cytokine production (IL-10 and IL-12p70) and maturation of mouse bone marrow-derived dendritic cells nor induced signaling through TLR2/TLR4 receptors. Also consistent with our findings, Górska et al. [10] showed that PS isolated from L. casei LOCK0919 (forms L919/A and L919/B) failed to induce the production of IL-8 in HEK293 cells expressing TLR2, TLR4, or NOD2. In addition, even though an increased TNF- $\alpha$ was observed for L919/B, L919/A failed to induce the production of pro- or anti-inflammatory cytokines, as respectively TNF- $\alpha$ and IL-10, in THP-1 cells. Thus, several studies, like ours, failed to assign evident immunostimulatory ability to PS which were sometimes depicted as immunologically inert molecules keeping microbe-associated molecular patterns (MAMPs) from direct contact with immune cell receptors [8,-54]. Nonetheless, using the THP-1 cell model, Balzaretti et al. [11] recently showed that PS isolated from L. paracasei DG displayed immunostimulatory properties by enhancing the gene expression of the proinflammatory cytokines TNF- $\alpha$ and IL-6 and, particularly, the chemokines IL-8 and CCL20, in accordance with other studies [46,55]. Similarly, in their study on the structural and immunomodulatory properties of PS isolated from lactobacilli sampled in the intestine of mice with experimentally induced Inflammatory Bowel Disease (IBD”+”) vs healthy mice, Górska et al. [56] found that the PS E142 of IBD"+" commensal L. johnsonii 142 was able to induce the differentiation of dendritic cells and trigger the production of cytokines, in contrast with PS from other IBD"+" strains. In addition, anti-inflammatory properties of lactobacilli PS have also been depicted, for instance in L. casei Shirota: PS suppressed pro-inflammatory cytokines responses in macrophages [8] while a cell-wall derived polysaccharide-peptidoglycan complex inhibited IL-6 production in LPSstimulated lamina propria mononuclear cells isolated from murine IBD [57]. Taken together, these results clearly indicate that effects of lactobacilli are species- and strain-dependent and only PS with specific chemical structures may induce an immune response. However, the possible artifacts due to a partial PS chemical characterization and the putative presence of lipo-contamination (e.g., lipoteichoic acid or LPS) cannot be ruled out $[9,58]$. Interestingly, PS alone induced less of an immune response 
than their whole bacteria counterparts [56]; nevertheless, they were able to efficiently modulate the immune response patterns elicited by other bacteria [9-10].

As shown above, numerous works have reported, or not, immunomodulatory activity of lactobacilli PS with immune cells like macrophages and dendritic cells; however, the first line of defense in the intestinal tract is the epithelial layer, a one-cell thick barrier that lines the gut lumen. Surprisingly, the potential of PS to interact with intestinal epithelial cells has often been neglected. Indeed, most studies focused in the capacity of PS-producing lactobacilli to adhere to intestinal epithelial cells [59-62] or the impact of PS in the immunobiology of these cells $[11,49,63]$. Here, we investigated for the first time the putative role of CWPS on the TNF- $\alpha /$ IFN- $\gamma$ cytokine-mediated epithelium impairment. We used T84 human intestinal epithelial cells, which have been recently described to have distinct morphological, biochemical and functional characteristics compared to Caco-2 cells [64]. In fact, T84 cells do not acquire the biochemical signature of mature small intestinal enterocytes as observed for Caco-2 cells, but retain much of their original colonic characteristics throughout differentiation. Previous work demonstrated that TNF- $\alpha$ and IFN- $\gamma$ act synergistically for inducing intestinal barrier dysfunction in intestinal HT29 cl.19A cells [28] and Caco-2 cells [65]. We thus considered a TNF$\alpha / \mathrm{IFN}-\mathrm{g}$ mixture at low and physiologically relevant levels $(10 \mathrm{ng} / \mathrm{mL})$ for our experiments with T84 cells. TEER was measured using the latest cellZScope ${ }^{\circledR}$ monitoring device which had the advantage of providing in situ and in real-time analysis. Therefore, an adapted protocol was established to reproduce cytokine-induced barrier dysfunction as discussed in the literature for Caco-2 cells, for which the majority of TEER values were measured by classical instrumentation [65-69]. We found that CWPS neither prevented cytokine-mediated epithelium impairment nor influenced intestinal barrier integrity under basal conditions (i.e. no pro-inflammatory cytokine challenge), in line with the results of Kishimoto et al. [58] who observed no change in TEER values of Caco-2 cells after addition of PS isolated from L. plantarum KM-9 or L. delbrueckii TU-1. Interestingly, in the mucus-secreting HT29-MTX intestinal epithelial cell line, the PS synthesized by L. paraplantarum BGCG11 was found 
to partially counteract the cellular damage caused by opportunistic pathogens even though it was not able to improve the expression of muc genes nor the secretion of mucus [70].

In conclusion, we studied the probiotic L. farciminis CIP 103136 in order to identify cell surface molecules that may be involved in crosstalk with the host supporting its well-known health-promoting properties. We found a novel cell-wall anchored polysaccharide, named CWPS, which is secreted by and covers the bacterium. We demonstrated that CWPS has a chemical structure never identified before. Nonetheless, it failed to influence biological activities in both macrophage- and colonocytelike cell models, and to modulate TLR2 or TLR4 cell-signaling pathways. Other properties of CWPS in bacteria/host but also bacteria/bacteria crosstalk could be investigated in the future, including the immune response modulation to third party antigens, bacteria protection against phagocytosis and biofilm formation.

\section{Acknowledgements}

The authors wish to acknowledge Lallemand SA (France) and Lallemand-Institut Rosell (Canada) for providing the L. farciminis strain.

\section{Compliance with ethical standards}

\section{Conflict of Interest}

The authors declare that they have no conflict of interest.

\section{Ethical approval}

This article does not contain any studies with human participants or animals performed by any of the authors. 


\section{References}

[1] Hill, C., Guarner, F., Reid, G., Gibson, G.R., Merenstein, D.J., Pot, B., Morelli, L., Canani, R.B.,

Flint, H.J., Salminen, S., Calder, P.C., Sanders, M.E.: Expert consensus document. The International Scientific Association for Probiotics and Prebiotics consensus statement on the scope and appropriate use of the term probiotic. Nat. Rev. Gastroenterol. Hepatol., 11, 506-514 (2014)

[2] McFarland, L.V.: From yaks to yogurt: the history, development, and current use of probiotics. Clin. Infect. Dis. 60, S85-90 (2015)

[3] Donato, K.A., Gareau, M.G., Wang, Y.J., Sherman, P.M.: Lactobacillus rhamnosus GG attenuates interferon-gamma and tumour necrosis factor-alpha-induced barrier dysfunction and pro-inflammatory signalling. Microbiology. 156, 3288-3297 (2010)

[4] Wells, J.M.: Immunomodulatory mechanisms of lactobacilli. Microb. Cell Fact. 10, S17 (2011)

[5] Lee, I.C., Tomita, S., Kleerebezem, M., Bron, P.A.: The quest for probiotic effector molecules-unraveling strain specificity at the molecular level. Pharmacol. Res. 69, 61-742013 (2013)

[6] Smits, H.H., Engering, A., van der Kleij, D., de Jong, E.C., Schipper, K., van Capel, T.M., Zaat, B.A., Yazdanbakhsh, M., Wierenga, E.A., van Kooyk, Y., Kapsenberg, M.L.: Selective probiotic bacteria induce IL-10-producing regulatory $\mathrm{T}$ cells in vitro by modulating dendritic cell function through dendritic cell-specific intercellular adhesion molecule 3-grabbing nonintegrin. J. Allergy Clin. Immunol. 115, 1260-1267 (2005) 
[7] Sengupta, R., Altermann, E., Anderson, R.C., McNabb, W.C., Moughan, P.J., Roy, N.C. The role of cell surface architecture of lactobacilli in host-microbe interactions in the gastrointestinal tract. Mediators Inflamm. 2013, 237921 (2013)

[8] Yasuda, E., Serata, M., Sako, T.: Suppressive effect on activation of macrophages by Lactobacillus casei strain Shirota genes determining the synthesis of cell wall-associated polysaccharides. Appl. Environ. Microbiol. 74, 4746-4755 (2008)

[9] Górska, S., Schwarzer, M., Jachymek, W., Srutkova, D., Brzozowska, E., Kozakova, H., Gamian, A.: Distinct immunomodulation of bone marrow-derived dendritic cell responses to Lactobacillus plantarum WCFS1 by two different polysaccharides isolated from Lactobacillus rhamnosus LOCK 0900. Appl Environ Microbiol. 80, 6506-6516 (2014)

[10] Górska, S., Hermanova, P., Ciekot, J., Schwarzer, M., Srutkova, D., Brzozowska, E., Kozakova, H., Gamian, A.: Chemical characterization and immunomodulatory properties of polysaccharides isolated from probiotic Lactobacillus casei LOCK 0919. Glycobiology. 26, 1014-1024 (2016)

[11] Balzaretti, S., Taverniti, V., Guglielmetti, S., Fiore, W., Minuzzo, M., Ngo, H.N., Ngere, J.B., Sadiq, S., Humphreys, P.N., Laws, A.P.: A novel rhamnose-rich hetero-exopolysaccharide isolated from Lactobacillus paracasei DG activates THP-1 human monocytic cells. Appl. Environ. Microbiol. 83, pii: e02702-16 (2017)

[12] Mazmanian, S.K, Kasper, D.L.: The love-hate relationship between bacterial polysaccharides and the host immune system. Nat. Rev. Immunol. 6, 849-858 (2006) 
[13] Mazmanian, S.K.: Capsular polysaccharides of symbiotic bacteria modulate immune responses during experimental colitis. J. Pediatr. Gastroenterol. Nutr. 46, E11-2 (2008)

[14] Mazmanian, S.K., Round, J.L., Kasper, D.L.: A microbial symbiosis factor prevents intestinal inflammatory disease. Nature. 453, 620-625 (2008)

[15] Lamine, F., Eutamène, H., Fioramonti, J., Buéno, L., Théodorou, V.: Colonic responses to Lactobacillus farciminis treatment in trinitrobenzene sulphonic acid-induced colitis in rats. Scand. J. Gastroenterol. 39, 1250-1258 (2004a)

[16] Lamine, F., Fioramonti, J., Bueno, L., Nepveu, F., Cauquil, E., Lobysheva, I., Eutamène, H., Théodorou, V.: Nitric oxide released by Lactobacillus farciminis improves TNBS-induced colitis in rats. Scand. J. Gastroenterol. 39, 37-45 (2004b)

[17] Ait-Belgnaoui, A., Han, W., Lamine, F., Eutamène, H., Fioramonti, J., Bueno, L., Théodorou, V.: Lactobacillus farciminis treatment suppresses stress induced visceral hypersensitivity: a possible action through interaction with epithelial cell cytoskeleton contraction. Gut. 55, 1090-1094 (2006).

[18] Da Silva, S., Robbe-Masselot, C., Ait Belgnaoui, A., Mancuso, A., Mercade-Loubière, M., Cartier, C., Gillet, M., Ferrier, L., Loubière, P., Dague, E., Théodorou, V., Mercier-Bonin, M.: Stress disrupts intestinal mucus barrier in rats via mucin O-glycosylation shift: prevention by a probiotic treatment. Am. J. Physiol. Gastrointest. Liver Physiol. 307, G420-G429 (2014)

[19] Tareb, R., Bernardeau, M., Horvath, P., Vernoux, J.P.: Rough and smooth morphotypes isolated from Lactobacillus farciminis CNCM I-3699 are two closely-related variants. Int. J. Food Microbiol. $193,82-90(2015)$ 
[20] Altman, E., Brisson, J.R., Perry, M.B.: Structure of the O-antigenpolysaccharide of Haemophilus pleuropneumoniae serotype 3 (ATCC 27090) lipopolysaccharide. Carbohyd. Res. 179, 245-258 (1988)

[21] Gerwig, G.J., Kamerling, J.P., Vliegenthart, J.F.: Determination of the absolute configuration of mono-saccharides in complex carbohydrates by capillary G.L.C. Carbohydr. Res. 77, 10-7 (1979)

[22] Ciucanu, I., Kerek, F.: A simple and rapid method for the permethylation of carbohydrates. Carbohyd. Res., 131, 209-217 (1984)

[23] Read, S.M., Currie, G., Bacic, A.: Analysis of the structural heterogeneity of laminarin by electrospray-ionisation-mass spectrometry. Carbohyd. Res., 281, 187-201 (1996)

[24] Dubois, M., Gilles., K.A., Hamilton, J.F., Rebers, P.A., Smyth, F.: Colorimetric methods for determination of sugars and related substances. Anal. Biochem. 28, 350-356 (1956)

[25] Gatt, R., Berman, E.R.: A rapid procedure for the estimation of amino sugars on a micro scale. Anal. Biochem. 15, 167-171 (1966)

[26] Tsuchiya, S., Yamabe, M., Yamaguchi, Y., Kobayashi, Y., Konno, T., Tada, K.: Establishment and characterization of a human acute monocytic leukemia cell line (THP-1). Int. J. Cancer. 26, 171176 (1980) 
[27] Daigneault, M., Preston, J.A., Marriott, H.M., Whyte, M.K.B., Dockrell, D.H.: The identification of markers of macrophage differentiation in PMA-stimulated THP-1 cells and monocyte-derived macrophages. PloS One, 5, e8668 (2010).

[28] Rodriguez, P., Heyman, M., Candalh, C., Blaton, M.A., Bouchaud, C.: Tumour necrosis factor- $\alpha$ induced morphological and functional alterations of intestinal HT29 cl.19A cell monolayers. Cytokine, 7, 441-448 (1995)

[29] Moreau, M., Richards, J.C., Fournier, J.M., Byrd, R.A., Karakawa, W.W., Vann, W.F. Structure of the type 5 capsular polysaccharide of Staphylococcus aureus. Carbohydr. Res. 201, 285-297 (1990)

[30] Prakobphol, A., Linzer, R., Genco, R.J.: Purification and characterization of a rhamnosecontaining cell wall antigen of Streptococcus mutans B13 (serotype d). Infect. Immun. 27, 150-157 (1980)

[31] Sadovskaya, I., Vinogradov, E., Courtin, P., Armalyte, J., Meyrand, M., Giaouris, E., Palussière, S., Furlan, S., Péchoux, C., Ainsworth, S., Mahony, J., van Sinderen, D., Kulakauskas, S., Guérardel, Y., Chapot-Chartier, M.P.: Another brick in the wall: a rhamnan polysaccharide trapped inside peptidoglycan of Lactococcus lactis. MBio. 8, pii: e01303-17 (2017)

[32] Goldstein, I.J., Hay, G.W., Lewis, B.A., Smith, F. Methods Carbohydr. Chem. 5, 361-370 (1965)

[33] Koerner, T.A., Prestegard, J.H., Yu, R.K.: Oligosaccharide structure by two-dimensional proton nuclear magnetic resonance spectroscopy. Methods Enzymol. 138, 38-59 (1987). 
[34] Aliprantis, A.O., Yang, R.B., Mark, M.R., Suggett, S., Devaux, B., Radolf, J.D., Klimpel, G.R., Godowski, P., Zychlinsky, A.: Cell activation and apoptosis by bacterial lipoproteins through Toll-like receptor-2. Science. 285, 736-739 (1999)

[35] Angulo, S., Llopis, M., Antolín, M., Gironella, M., Sans, M., Malagelada, J.R., Piqué, J.M., Guarner, F., Panés, J.: Lactobacillus casei prevents the upregulation of ICAM-1 expression and leukocyte recruitment in experimental colitis. Am. J. Physiol. Gastrointest. Liver Physiol. 291, G1155$1162(2006)$

[36] Elass-Rochard, E., Rombouts, Y., Coddeville, B., Maes, E., Blervaque, R., Hot, D., Kremer, L., Guérardel, Y.: Structural determination and Toll-like receptor 2-dependent proinflammatory activity of dimycolyl-diarabino-glycerol from Mycobacterium marinum. J. Biol. Chem. 287, 34432-34444 (2012)

[37] Prieto, J., Eklund, A., Patarroyo, M.: Regulated expression of integrins and other adhesion molecules during differentiation of monocytes into macrophages. Cell. Immunol., 156, 191-211 (1994)

[38] Lebedeva, T., Dustin, M.L, Sykulev, Y.: ICAM-1 co-stimulates target cells to facilitate antigen presentation. Curr. Opin. Immunol. 17, 251-258 (2005)

[39] Ryan, P.M., Ross, R.P., Fitzgerald, G.F., Caplice, N.M., Stanton, C.: Sugar-coated: exopolysaccharide producing lactic acid bacteria for food and human health applications. Food Funct. 6, 679-693 (2015) 
[40] Choudhury, B., Leoff, C., Saile, E., Wilkins, P., Quinn, C.P., Kannenberg, E.L., Carlson, R.W.

The structure of the major cell wall polysaccharide of Bacillus anthracis is species-specific. J. Biol. Chem. 281, 27932-27941 (2006)

[41] Candela, T., Maes, E., Garenaux, E., Rombouts, Y., Krzewinski, F., Gohar, M., Guerardel, Y.: Environmental and biofilm-dependent changes in a Bacillus cereus secondary cell wall polysaccharide. J. Biol. Chem., 286, 31250-31262 (2011)

[42] Forsberg, L.S., Choudhury, B., Leoff, C., Marston, C.K., Hoffmaster, A.R., Saile, E., Quinn, C.P., Kannenberg, E.L., Carlson, R.W.: Secondary cell wall polysaccharides from Bacillus cereus strains G9241, 03BB87 and 03BB102 causing fatal pneumonia share similar glycosyl structures with the polysaccharides from Bacillus anthracis. Glycobiology. 21, 934-948 (2011)

[43] Nagaoka, M., Muto, M., Nomoto, K., Matuzaki, T., Watanabe, T., Yokokura, T.: Structure of polysaccharide-peptidoglycan complex from the cell wall of Lactobacillus casei YIT9018. J. Biochem. $108,568-571(1990)$

[44] Vinogradov, E., Sadovskaya, I., Grard, T., Chapot-Chartier M,P.: Structural studies of the rhamnose-rich cell wall polysaccharide of Lactobacillus casei BL23. Carbohydr Res. 435, 156-161 (2016)

[45] Vinogradov, E., Valence, F., Maes, E., Jebava, I., Chuat, V., Lortal, S., Grard, T., Guerardel, Y., Sadovskaya, I.: Structural studies of the cell wall polysaccharides from three strains of Lactobacillus helveticus with different autolytic properties: DPC4571, BROI, and LH1. Carbohydr. Res. 379, 7-12 (2013) 
[46] Ciszek-Lenda, M., Nowak, B., Srottek, M., Gamian, A., Marcinkiewicz, J.: Immunoregulatory potential of exopolysaccharide from Lactobacillus rhamnosus KL37: effects on the production of inflammatory mediators by mouse macrophages. Int. J. Exp. Pathol. 92, 382-391 (2011)

[47] Gao, K., Wang, C., Liu, L., Dou, X., Liu, J., Yuan, L., Zhang, W., Wang, H.: Immunomodulation and signaling mechanism of Lactobacillus rhamnosus GG and its components on porcine intestinal epithelial cells stimulated by lipopolysaccharide. J. Microbiol. Immunol. Infect. 50, 700-713 (2017)

[48] Liu, C.F., Tseng, K.C., Chiang, S.S., Lee, B.H., Hsu, W.H., Pan, T.M.: Immunomodulatory and antioxidant potential of Lactobacillus exopolysaccharides. J. Sci. Food Agric. 91, 2284-2291 (2011)

[49] Patten, D.A., Leivers, S., Chadha, M.J., Maqsood, M., Humphreys, P.N., Laws, A.P., Collett, A.: The structure and immunomodulatory activity on intestinal epithelial cells of the EPSs isolated from Lactobacillus helveticus sp. rosyjski and Lactobacillus acidophilus sp. 5e2. Carbohydr. Res. 384, 119$127(2014)$

[50] Patten, D.A., Laws, A.P. Lactobacillus-produced exopolysaccharides and their potential health benefits: a review. Benef. Microbes. 6, 457-471 (2015)

[51] Shao, L., Wu, Z., Zhang, H., Chen, W., Ai, L., Guo, B.: Partial characterization and immunostimulatory activity of exopolysaccharides from Lactobacillus rhamnosus KF5. Carbohyd. Polym. 107, 51-56 (2014)

[52] Vinderola, G., Perdigon, G., Duarte, J., Farnworth, E., Matar, C.: Effects of the oral administration of the exopolysaccharide produced by Lactobacillus kefiranofaciens on the gut mucosal immunity. Cytokine. 36, 254-260 (2006) 
[53] Chanput, W., Mes, J.J., Wichers, H.J.: THP-1 cell line: An in vitro cell model for immune modulation approach. Int. Immunopharmacol. 23, 37-45 (2014)

[54] Lebeer, S., Claes, I.J., Verhoeven, T.L., Vanderleyden, J., De Keersmaecker, S.C.: Exopolysaccharides of Lactobacillus rhamnosus GG form a protective shield against innate immune factors in the intestine. Microb. Biotechnol. 4, 368-374 (2011)

[55] Chabot, S., Yu, H-L., Léséleuc, L.D., Cloutier, D., Van Calsteren, M-R., Lessard, M., Roy, D., Lacroix, M., Oth, D. Exopolysaccharides from Lactobacillus rhamnosus RW-9595M stimulate TNF. Lait. 81, 683-697 (2001)

[56] Górska, S., Sandstrőm, C., Wojas-Turek, J., Rossowska, J., Pajtasz-Piasecka, E., Brzozowska, E., Gamian, A.: Structural and immunomodulatory differences among lactobacilli exopolysaccharides isolated from intestines of mice with experimentally induced inflammatory bowel disease. Sci. Rep. 6, $37613(2016)$

[57] Matsumoto, S., Hara, T., Nagaoka, M., Mike, A., Mitsuyama, K., Sako, T., Yamamoto, M., Kado, S., Takada, T.: A component of polysaccharide peptidoglycan complex on Lactobacillus induced an improvement of murine model of inflammatory bowel disease and colitis-associated cancer. Immunology. 128, e170-80 (2009)

[58] Kishimoto, M., Nomoto, R., Mizuno, M., Osawa, R.: An in vitro investigation of immunomodulatory properties of Lactobacillus plantarum and L. delbrueckii cells and their extracellular polysaccharides. Biosci. Microbiota Food Health. 36, 101-110 (2017) 
[59] Lebeer, S., Verhoeven, T.L.A., Francius, G., Schoofs, G., Lambrichts, I., Dufrêne, Y., Vanderleyden, J., De Keersmaecker, S.C.J.: Identification of a gene cluster for the biosynthesis of a long, galactose-rich exopolysaccharide in Lactobacillus rhamnosus GG and functional analysis of the priming glycosyltransferase. Appl. Environ. Microbiol. 75, 3554-3563 (2009)

[60] Górska-Frączek, S., Sandstrom, C., Kenne, L., Rybka, J., Strus, M., Heczko, P., Gamian, A.: Structural studies of the exopolysaccharide consisting of a nonasaccharide repeating unit isolated from Lactobacillus rhamnosus KL37B. Carbohydr. Res. 346, 2926-2932 (2011)

[61] Nikolic, M., López, P., Strahinic, I., Suárez, A., Kojic, M., Fernández-García, M., Topisirovic, L., Golic, N., Ruas-Madiedo, P.: Characterisation of the exopolysaccharide (EPS)-producing Lactobacillus paraplantarum BGCG11 and its non-EPS producing derivative strains as potential probiotics. Int. J. Food Microbiol. 158, 155-162 (2012)

[62] Polak-Berecka, M., Waśko, A., Paduch, R., Skrzypek, T., Sroka-Bartnicka, A.: The effect of cell surface components on adhesion ability of Lactobacillus rhamnosus. Antonie Van Leeuwenhoek. 106, $751-762(2014)$

[63] Wachi, S., Kanmani, P., Tomosada, Y., Kobayashi, H., Yuri, T., Egusa, S., Shimazu, T., Suda, Y., Aso, H., Sugawara, M., Saito, T., Mishima, T., Villena, J., Kitazawa H. Lactobacillus delbrueckii TUA4408L and its extracellular polysaccharides attenuate enterotoxigenic Escherichia coli-induced inflammatory response in porcine intestinal epitheliocytes via Toll-like receptor-2 and 4. Mol. Nutr. Food Res., 58, 2080-2093 (2014) 
[64] Devriese, S., Van den Bossche, L., Van Welden, S., Holvoet, T., Pinheiro, I., Hindryckx, P., De Vos, M., Laukens, D.: T84 monolayers are superior to Caco-2 as a model system of colonocytes. Histochem. Cell Biol. 148, 85-93 (2017)

[65] Wang, F., Graham, W.V., Wang, Y., Witkowski, E.D., Schwarz, B.T., Turner J.R.: Interferongamma and tumor necrosis factor-alpha synergize to induce intestinal epithelial barrier dysfunction by up-regulating myosin light chain kinase expression. Am. J. Pathol. 166, 409- 419 (2005)

[66] Contreras, T. C., Ricciardi, E., Cremonini, E., Oteiza, P.I.: (-)-Epicatechin in the prevention of tumor necrosis alpha-induced loss of Caco-2 cell barrier integrity. Arch. Biochem. Biophys. 573, 84$91(2015)$

[67] Cui, W., Li, L.X., Sun, C.M., Wen, Y., Zhou, Y., Dong, Y.L., Liu, P.: Tumor necrosis factor alpha increases epithelial barrier permeability by disrupting tight junctions in Caco-2 cells. J. Med. Biol. Res. 43, 330- 337 (2010)

[68] Hsieh, C.Y., Osaka, T., Moriyama, E., Date, Y., Kikuchi, J., Tsuneda, S.: Strengthening of the intestinal epithelial tight junction by Bifidobacterium bifidum. Physiol. Rep. 3, 12327 (2015)

[69] Kawaguchi, H., Akazawa, Y., Watanabe, Y., Takakura, Y. Permeability modulation of human intestinal Caco-2 cell monolayers by interferons. Eur. J. Pharm. Biopharm. 59, 45-50 (2005)

[70] Zivkovic, M., Hidalgo-Cantabrana, C., Kojic, M., Gueimonde, M., Golic, N., Ruas-Madiedo, P.: Capability of exopolysaccharide-producing Lactobacillus paraplantarum BGCG11 and its nonproducing isogenic strain NB1, to counteract the effect of enteropathogens upon the epithelial cell line HT29-MTX. Food Res. Int. 74, 199-207 (2015) 


\section{Tables}

Table 1. ${ }^{1} \mathrm{H}-{ }^{13} \mathrm{C}$ NMR data of backbone chain of the CWPS following smith degradation. Values in bold correspond to substitution positions.

Chemical shifts

\begin{tabular}{|c|c|c|c|c|c|c|c|c|}
\hline & H1-C1 & H2-C2 & H3-C3 & H4-C4 & H5-C5 & H6/6'-C6 & $\mathrm{C}^{1} \underline{\mathbf{H}}_{3}$ & ${ }^{13} \mathrm{CH}_{3}$ \\
\hline A $\alpha$-GlcNAc & $5.23-99.5$ & $3.87-55.0$ & $3.70-71.9$ & $3.47-71.0$ & $3.80-72.8$ & $4.11 / 3.83-69.4$ & \multirow{2}{*}{2,03} & \multirow{2}{*}{23,3} \\
\hline $\mathbf{A}^{\prime} \alpha$-GlcNAc* & $5.28-99.3$ & $3.91-55.0$ & $3.70-71.9$ & $3.47-71.0$ & $3.80-72.8$ & $4.11 / 3.83-69.4$ & & \\
\hline B $\beta$-ManNAc & $4.89-100.8$ & $4.51-55.0$ & $4.06-74.0$ & $3.72-80.1$ & $3.57-76.5$ & $3.90 / 3.80-61.9$ & 2,06 & 23,3 \\
\hline C $\beta$-GlcNAc & $4.54-102.8$ & $3.77-56.22$ & $3.71-73.5$ & $3.71-80.2$ & $3.51-75.8$ & $3.87 / 3.74-61.8$ & 2,07 & 23,3 \\
\hline
\end{tabular}

* is the terminal reductive ( $\alpha$ GlcNAc) form of the main chain after Smith degradation.

Table 2. Proton and carbon chemical shifts of the monosaccharides from native polysaccharide. nd: data not determined. Values in bold correspond to substitution positions.

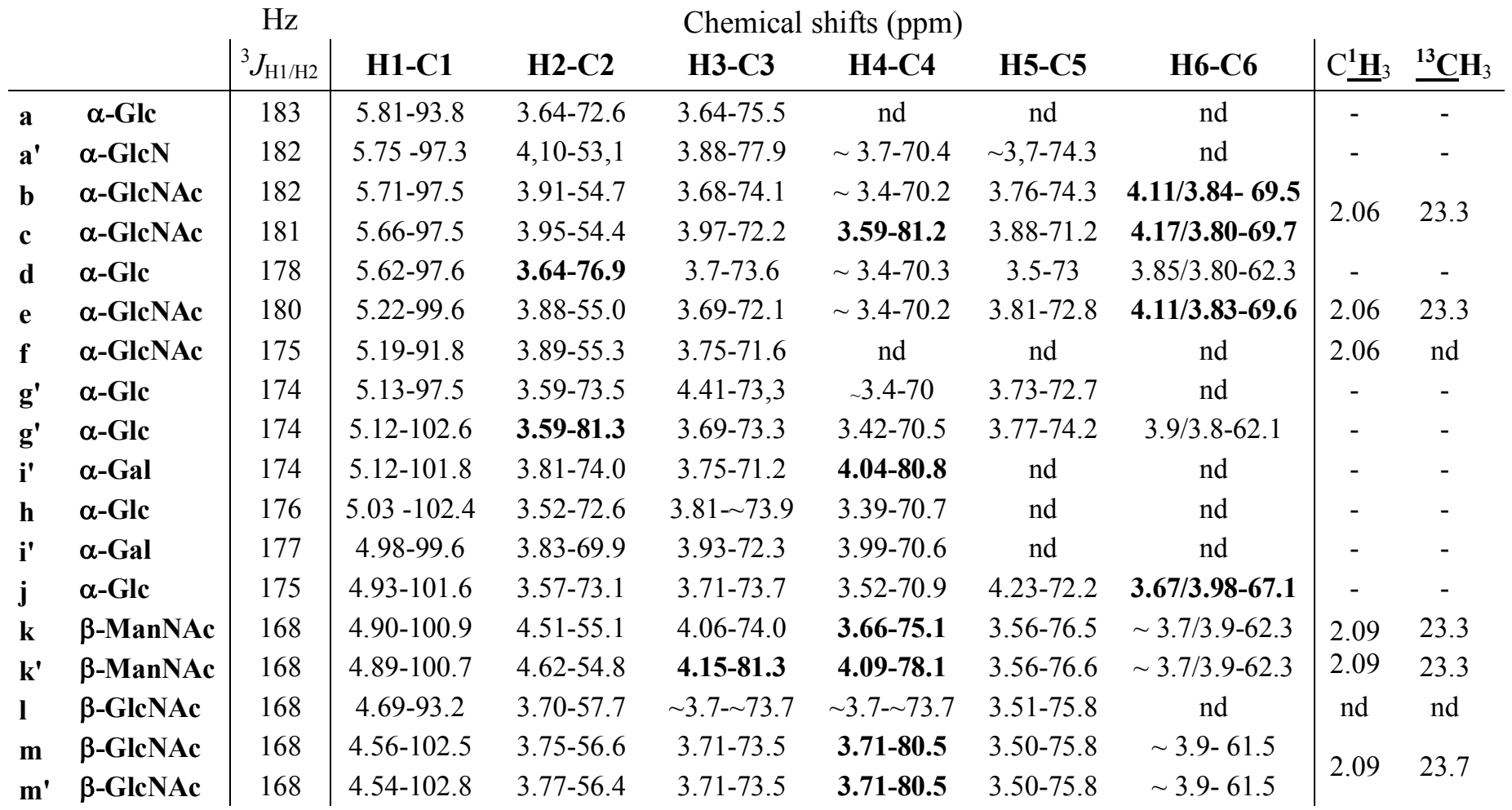

Table 3. Relevant nOe contacts and ${ }^{3} J_{\mathrm{H}, \mathrm{C}}$ connections observed on intact HMWP. Spectra were recorded at $21.4 \mathrm{~T}$. 


\begin{tabular}{|c|c|c|}
\hline & nOe ${ }^{1} \mathrm{H}-{ }^{1} \mathrm{H}$ & $\mathrm{HMBC}^{3} \boldsymbol{J}_{\mathrm{H}, \mathrm{C}}$ \\
\hline $\mathbf{a}^{\prime}$ & $\mathrm{H} 1 \mathbf{a}^{\prime} \rightarrow \mathrm{H} 1 \mathbf{g}$ & \\
\hline b & $\mathrm{H} 1 \mathbf{b} \rightarrow \mathrm{H} 3 \mathbf{k}^{\prime}$ & \\
\hline b & $\mathrm{H} 1 \mathbf{b} \rightarrow \mathrm{H} 4 \mathbf{k}^{\prime}$ & $\mathrm{H} 1 \mathbf{b} \rightarrow \mathrm{C} 4 \mathbf{k}^{\prime}$ \\
\hline c & $\mathrm{H} 1 \mathbf{c} \rightarrow \mathrm{H} 3 \mathbf{k}^{\prime}$ & \\
\hline c & $\mathrm{H} 1 \mathbf{c} \rightarrow \mathrm{H} 4 \mathbf{k}^{\prime}$ & \\
\hline d & & $\mathrm{H} 1 \mathrm{~d} \rightarrow \mathrm{C} 4 \mathrm{c}$ \\
\hline $\mathbf{e}$ & $\mathrm{H} 1 \mathbf{e} \rightarrow \mathrm{H} 3 \mathbf{k}$ & $\mathrm{H} 1 \mathbf{e} \rightarrow \mathrm{C} 4 \mathbf{k}$ \\
\hline $\mathbf{e}$ & $\mathrm{H} 1 \mathbf{e} \rightarrow \mathrm{H} 4 \mathbf{k}$ & \\
\hline g & $\mathrm{H} 1 \mathbf{g} \rightarrow \mathrm{H} 3 \mathbf{k}^{\prime}$ & $\mathrm{H} 1 \mathbf{g} \rightarrow \mathrm{C} 3 \mathbf{k}^{\prime}$ \\
\hline$g^{\prime}$ & & $\mathrm{H} 1 \mathbf{g}^{\prime} \rightarrow \mathrm{C} 2 \mathbf{d}$ \\
\hline h & $\mathrm{H} 1 \mathbf{h} \rightarrow \mathrm{H} 3 \mathbf{k}^{\prime}$ & \\
\hline i & $\mathrm{H} 1 \mathbf{i} \rightarrow \mathrm{H} 6 \mathbf{j}$ & $\mathrm{H} 1 \mathbf{i} \rightarrow \mathrm{C} 6 \mathbf{j}$ \\
\hline $\mathbf{i}^{\prime}$ & & $\mathrm{H} 1 \mathbf{i}^{\prime} \rightarrow \mathrm{C} 3 \mathbf{k}^{\prime}$ \\
\hline j & $\mathrm{H} 1 \mathbf{j} \rightarrow \mathrm{H} 4 \mathbf{i}^{\prime}$ & $\mathrm{H} 1 \mathbf{j} \rightarrow \mathrm{C} 4 \mathbf{i}^{\prime}$ \\
\hline $\mathbf{k} / \mathbf{k}^{\prime}$ & $\mathrm{H} 1 \mathbf{k} / \mathbf{k}^{\prime} \rightarrow \mathrm{H} 4 \mathbf{m} / \mathbf{m}^{\prime}$ & $\mathrm{H} 1 \mathbf{k} / \mathbf{k}^{\prime} \rightarrow \mathrm{C} 4 \mathbf{m} / \mathbf{m}^{\prime}$ \\
\hline m & $\mathrm{H} 1 \mathbf{m} \rightarrow \mathrm{H} 6 / 6 \mathbf{e}$ & \\
\hline $\mathbf{m}^{\prime}$ & $\mathrm{H} 1 \mathbf{m}^{\prime} \rightarrow \mathrm{H} 6 / 6^{\prime} \mathbf{b}$ & $\mathrm{H} 1 \mathbf{m}^{\prime} \rightarrow \mathrm{C} 6 \mathbf{b}$ \\
\hline
\end{tabular}




\section{Figure captions}

Fig. 1 Transmission electron micrograph of L. farciminis CIP 103136. Arrows indicate the bacterial cell wall (white arrow) and the CWPS layer (black arrow). Scale bar: $200 \mathrm{~nm}$.

Fig. $2{ }^{1}$ H-NMR spectra of L. farciminis CWPS before (A) and after (B) Smith degradation.

Fig. $3{ }^{1} \mathrm{H} /{ }^{13} \mathrm{C}-\mathrm{HSQC}$ NMR spectrum of $L$. farciminis CWPS backbone structure. CWPS was subjected to periodic oxidation and analyzed by ${ }^{1} \mathrm{H} /{ }^{13} \mathrm{C}-\mathrm{NMR}$. Identification of the spin systems and individual chemical shifts established the nature of the polysaccharide backbone as the trisaccharide repeat unit $[\rightarrow 6) \alpha \operatorname{Glc} p N A c(1 \rightarrow 4) \beta \operatorname{Man} p N A c(1 \rightarrow 4) \beta \operatorname{Glc} p \mathrm{NAc}(1 \rightarrow]$. In blue, $-\underline{\mathrm{CH}}-\mathrm{OH}$ signals of the ring carbons; in red, $-\underline{\mathrm{CH}}_{2}-\mathrm{OH}$ signals of the $\mathrm{C} 6$.

Fig. 4 Mass spectrometry analysis of L. farciminis CWPS backbone structure. CWPS was subjected to periodic oxidation and analyzed by MALDI-MS/MS. (A) The MALDI-MS spectrum of backbone polysaccharide shows the presence of two related polysaccharides $\left[\mathrm{HexNac}_{3}\right]_{\mathrm{n}}$-Gro $(*)$ and $\left[\mathrm{HexNac}_{3}\right]_{\mathrm{p}}-\mathrm{HexNAc} \mathrm{C}_{2}$-Gro (**) with $\mathrm{m} / \mathrm{z}$ increments of 609 mass units core-responding to $\mathrm{HexNAc}_{3}$ repeat unit. (B) The MS/MS fragmentation spectrum of parent ion at $m / z 1739$ demonstrated that CWPS backbone is composed of a linear stretch of HexNAc residues with a glycerol (Gro) residue.

Fig. $5{ }^{1} \mathrm{H} /{ }^{13} \mathrm{C}$-HSQC NMR analysis of $L$. farciminis native CWPS. Detail of the anomeric region of ${ }^{1} \mathrm{H} /{ }^{13} \mathrm{C}$-HSQC NMR spectrum shows eighteen different anomer signals associated with substoechiometric substitution pattern of the backbone structure $[\rightarrow 6) \alpha \operatorname{Glc} p \operatorname{NAc}(1 \rightarrow 4) \beta \operatorname{Man} p \operatorname{NAc}(1 \rightarrow 4) \beta \operatorname{Glc} p \operatorname{NAc}(1 \rightarrow]$ 
Fig. $6{ }^{1} \mathrm{H} /{ }^{13} \mathrm{C}-\mathrm{HSQC}$ NMR analysis of $L$. farciminis native CWPS. Detail of the ring region of ${ }^{1} \mathrm{H} /{ }^{13} \mathrm{C}$ HSQC NMR spectrum showing substitution pattern of the polysaccharide. In blue, $-\underline{\mathrm{CH}}-\mathrm{OH}$ signals of the ring carbons; in red, $-\underline{\mathrm{CH}_{2}}-\mathrm{OH}$ signals of the $\mathrm{C} 6$.

Fig. 7 Modulatory effects of CWPS on cytokines secretion by macrophages-like THP-1 cells. Differentiated THP-1 cells were incubated with increasing concentrations (from 1 to $200 \mu \mathrm{g} / \mathrm{mL}$ ) of purified CWPS alone or with $0.5 \mu \mathrm{g} / \mathrm{mL}$ of $\mathrm{Pam}_{3} \mathrm{CSK}$. Culture supernatants were collected after $8 \mathrm{~h}$ or $24 \mathrm{~h}$ and assayed by ELISA for TNF- $\alpha$ (A) or IL-1 $\beta$ (B). CWPS was added simultaneously with $\mathrm{Pam}_{3} \mathrm{CSK}$ or pre-incubated with cells for $20 \mathrm{~h}$, before addition of lipopeptide (C, D). Then, TNF- $\alpha$ and IL1- $\beta$ secretion was quantified, as described in the section Materials and Methods. Data are expressed as means $\pm \mathrm{SD}$ of triplicates and are representative from three independent experiments. ${ }^{*} p>0.05$ indicates not significant difference $(n s)$ between CWPS-treated and unstimulated cells $(\mathrm{A}, \mathrm{B})$ or between $\mathrm{Pam}_{3} \mathrm{CSK}+\mathrm{CWPS}$ and $\mathrm{Pam}_{3} \mathrm{CSK}(\mathrm{C}, \mathrm{D}) .{ }^{* *} p<0.001$ with $\mathrm{Pam}_{3} \mathrm{CSK}$ vs unstimulated cells.

Fig. 8 Cell surface antigen expression on THP-1 cells incubated with CWPS. Monocyte and macrophage-like THP-1 cells were unstimulated (1) or incubated with CWPS $(50 \mu \mathrm{g} / \mathrm{mL})$ alone $(2$ : grey peak), $\operatorname{Pam}_{3} \mathrm{CSK}\left(0.5 \mu \mathrm{g} / \mathrm{mL}\right.$ ) alone (3) or with a mixture of CWPS+Pam ${ }_{3} \mathrm{CSK}$ (4). After $24 \mathrm{~h}$ of incubation, ICAM-1 (CD54) expression was determined by flow cytometry, using PE-conjugated antiCD54. Cells were also exposed with irrelevant antibodies (PE-conjugated mouse isotype controls) to evaluate non-specific binding of immunoglobulin (5). The results presented are from one representative experiment out of three independent experiments with similar results.

Fig. 9 Stimulation by CWPS of HEK-blue transfected with either hTLR2 and hTLR4. Cells were activated for $16 \mathrm{~h}$ with CWPS (from 100 to $350 \mu \mathrm{g} / \mathrm{mL}$ ) alone or in presence of TLR2 or TLR4 agonists, such as Pam ${ }_{3} \mathrm{CSK}(0.5 \mu \mathrm{g} / \mathrm{mL})$ and LPS $(50 \mathrm{ng} / \mathrm{mL})$. In some assays, CWPS was preincubated with cells for $4 \mathrm{~h}$, before addition of $\mathrm{Pam}_{3} \mathrm{CSK}$ or LPS. Stimulation was evaluated by 
measuring the SEAP activity in medium, at $\mathrm{OD}_{620}$ using the QUANTI-Blue detection assay. Results are expressed as means \pm S.D. of triplicates and are representative of three independent experiments. ${ }^{*} p>0.05$ was not significant $(n s) .{ }^{*} p<<0.001$ with Pam $_{3}$ CSK or LPS $v s$ unstimulated cells.

Fig. 10 Influence of CWPS against TNF- $\alpha /$ IFN- $\gamma$ induced epithelial barrier dysfunction in T84 cells. CWPS $(200 \mu \mathrm{g} / \mathrm{mL})$ was added to the apical compartment $24 \mathrm{~h}$ prior to the addition of TNF- $\alpha / \mathrm{IFN}-\gamma$ (10 ng/mL) to the basolateral side. TEER was continuously monitored before and after basolateral TNF- $\alpha /$ IFN- $\gamma$ exposure over a total incubation time of $54 \mathrm{~h}$. All data are expressed as percentage of control and represent means \pm SEM $(n=3)$. Asterisks indicate significant differences from the control group $(* * p<0.01)$. The TNF- $\alpha / \mathrm{IFN}-\gamma$ challenge at a dose of $10 \mathrm{ng} / \mathrm{mL}$ showed time-dependent TEER loss, which was not reversed by CWPS pre-treatment. CWPS alone had no effect on the epithelial barrier integrity. 